\title{
The Boom and Bust of U.S. Housing Prices from Various Geographic Perspectives
}

\author{
Jeffrey P. Cohen, Cletus C. Coughlin, and David A. Lopez
}

\begin{abstract}
This paper summarizes changes in housing prices during the recent U.S. boom and bust from various geographic perspectives. Nationally, the Standard \& Poor's/Case-Shiller house price index more than doubled in nominal terms during the boom and has fallen by roughly a third subsequently. During the boom, housing prices tended to rise much faster in metropolitan areas in the East and West Coast regions than in the country's interior. After adjusting for inflation, 7 of 19 metropolitan areas have experienced real declines in housing prices from the start of the boom to the present. Although lower-priced houses showed a larger percentage increase during the boom, higher-priced houses fared relatively better over the boom and bust. Changes in land prices, which are not easily measured, appear to have driven housing prices to a greater extent than changes in the prices of housing structures. Internationally, seven countries experienced housing booms and busts; however, these countries tended to have larger booms and smaller absolute busts than the United States. (JEL R31)
\end{abstract}

Federal Reserve Bank of St. Louis Review, September/October 2012, 94(5), pp. 341-67.

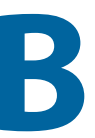
eginning in the late 1990s, U.S. housing prices rose substantially and subsequently fell sharply. 1 Because many jobs are related to the value of housing through spending by households and the public sector, especially local governments, the recent swings in housing prices and housing-related employment have had significant macroeconomic and microeconomic consequences. 2 Not surprisingly, interest in the movements of housing prices over time and across geographic areas has heightened.

This paper is primarily a descriptive review of the recent boom and bust in U.S. housing prices from various geographic perspectives. Our focus is on presenting facts rather than providing explanations for the housing price changes. Thus, we do not present models of house price determination. Nor do we examine the literature assessing the importance of fundamentals (e.g., wages and interest rates) for housing prices changes or the effect of other factors that contribute to bubbles. However, numerous references providing and examining explanations for the housing bubble, as well as housing price changes in its aftermath, are presented throughout the paper. $\underline{3}$ Admittedly, the cited references are only a subset of the existing literature.

Jeffrey P. Cohen is an associate professor of economics at the University of Hartford. Cletus C. Coughlin is senior vice president and policy adviser to the president, and David A. Lopez is a senior research associate at the Federal Reserve Bank of St. Louis. Jeffrey P. Cohen acknowledges support by the Lincoln Institute of Land Policy and the University of Hartford.

( ) 2012, The Federal Reserve Bank of St. Louis. The views expressed in this article are those of the author(s) and do not necessarily reflect the views of the Federal Reserve System, the Board of Governors, or the regional Federal Reserve Banks. Articles may be reprinted, reproduced, published, distributed, displayed, and transmitted in their entirety if copyright notice, author name(s), and full citation are included. Abstracts, synopses, and other derivative works may be made only with prior written permission of the Federal Reserve Bank of St. Louis. 


\section{Cohen, Coughlin, Lopez}

We examine both national and metropolitan area changes in housing prices. Our review of metropolitan areas allows for comparisons across these areas and, more generally, across regions. In addition, we review changes in prices within and across metropolitan areas by housing tiers. For example, housing prices in a metropolitan area are grouped into three categories: low, middle, and high tiers. Then, within a metropolitan area, the behavior of prices across the three categories is compared and, across metropolitan areas, the behavior of prices for each category is compared. To complete our review, we compare the recent U.S. experience with those of numerous advanced foreign economies.

A portion of our review of national and metropolitan area housing prices examines the changes in land prices and structure prices separately over the boom and bust periods. As stressed by Davis and Heathcote (2007) and Davis and Palumbo (2008), the price of a house can be separated into its physical structure, which is reproducible, and a plot of land, which is nonreproducible. These components serve different functions. The physical structure is an essential input for housing services as well as for leisure, while land, especially its geographic location, plays a key role in access to employment, public goods, and amenities.

These different functions and their varying degrees of reproducibility suggest that physical structures and land are priced differently. As a result, it is not surprising that the prices of structures and land behave differently over time. Especially useful for our analysis are the estimates generated by Davis and his co-authors $(2007,2008)$ of these prices over time, covering the recent U.S. housing price boom and bust for the nation overall and many individual metropolitan areas. The extent of the boom and bust has varied across metropolitan areas. The Davis datasets and other research allow us to assess how changes in the prices of land and structures have individually contributed to the changes in housing prices. $\frac{4}{}$

\section{NATIONAL HOUSING PRICES}

We begin by reviewing recent changes in housing prices at the national level. Exact dating of the beginning of the boom and the beginning of the bust depends on the dataset used to measure national housing prices. We select dates that are generally consistent with multiple datasets. We date the beginning of the boom as 1998:Q1. The start of the bust likely occurred in 2006; we date the end of the boom and the beginning of the bust as 2006:Q2. Generally speaking, the bust (or post-boom) period runs through 2012:Q1; however, at this time some metropolitan and international data are available only through an earlier date. As will become readily apparent, disagreements occur regarding the precise timing of the boom and bust periods. Even if consensus is reached on the national boom and bust dates, there is still considerable variation across individual metropolitan areas. Such variation also exists across countries, but not all countries have experienced housing price changes that can be characterized as a boom and bust. For our comparisons, we use the national dates, as defined above, for our comparisons.

\section{Some Basic Facts on the Boom and the Bust}

Many indexes measure national housing prices; here we focus on two standard measures: the Standard \& Poor's (S\&P)/Case-Shiller house price index and the Federal Housing Finance Agency (FHFA) Purchase-Only House Price Index. $\underline{5}$ Figure 1 provides two views of the national 


\section{Figure $1 \mathrm{~A}$}

\section{S\&P/Case-Shiller House Price Index (1991:Q1-2012:Q1)}

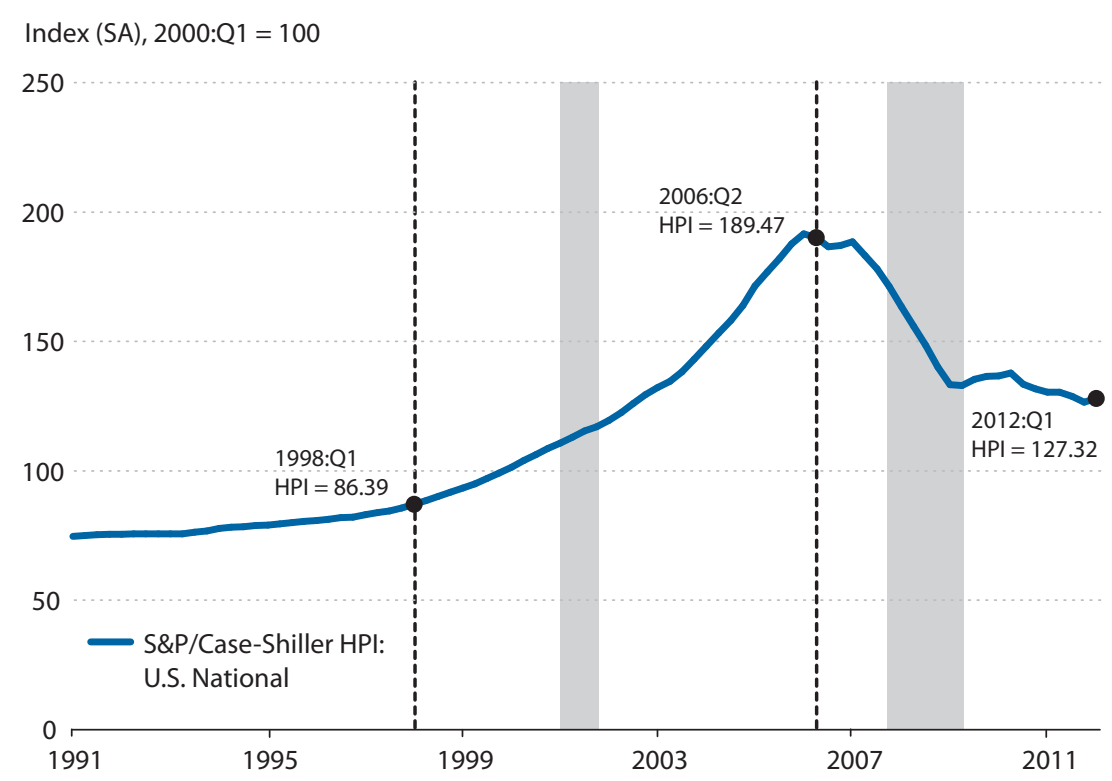

NOTE: The shaded areas indicate U.S. recessions as determined by the National Bureau of Economic Research. HPI, house price index; SA, seasonally adjusted.

\section{Figure 1B}

\section{Core PCE Rate and Year-Over-Year Changes in the S\&P/Case-Shiller HPI (1991:Q1-2012:Q1)}

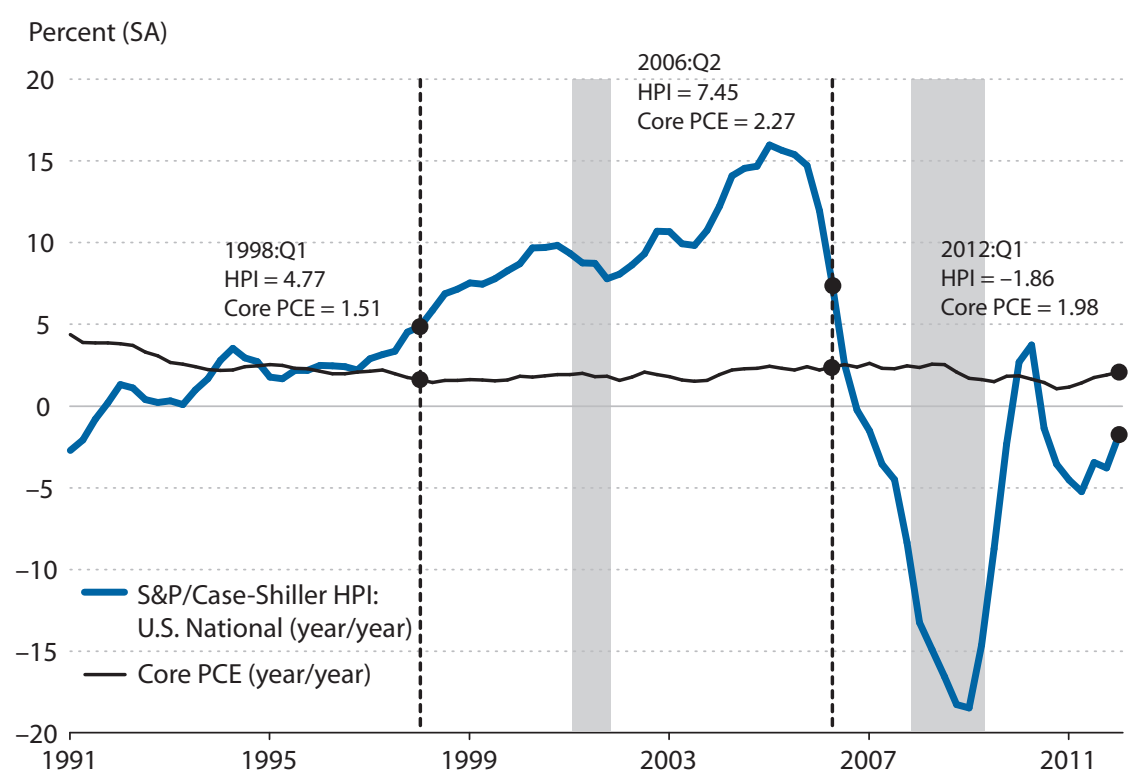

NOTE: The shaded areas indicate U.S. recessions. HPI, house price index; SA, seasonally adjusted. 


\section{Cohen, Coughlin, Lopez}

S\&P/Case-Shiller index since 1991. Figure 1A shows the level, while Figure 1B shows the yearover-year changes in this quarterly index. As Figure 1A shows, the level of this index began to increase at a faster pace beginning in 1998:Q1. It peaked in 2006:Q1 and subsequently has generally declined to its present level (as of 2012:Q1).

Meanwhile, Figure 1B highlights the following: (i) the significantly larger increases on a year-over-year basis in housing prices during the boom period and the subsequent general decline in house prices, (ii) the faster pace of housing price increases relative to the core inflation personal consumption expenditure (PCE) index during the boom, and (iii) the faster growth of the core inflation PCE index relative to the pace of housing price changes during the subsequent period. In nominal terms, housing prices more than doubled, with an increase of 119 percent during the boom period and a decline of 33 percent during the bust period. Overall housing prices increased 47 percent during the entire period (1998:Q1-2012:Q1).

The view changes slightly when housing prices are expressed in inflation-adjusted terms. Using the core inflation PCE index (see Figure 1B), housing prices increased 89 percent during the boom period and decreased 39 percent during the bust period. 6 The overall housing price increase was 14 percent.

Figure 2 shows two views of the FHFA Purchase-Only House Price Index since 1991. Figure 2A shows that the level of this index began to increase at a faster pace beginning in 1998:Q1. It peaked in 2007:Q1 and has subsequently generally declined to its present level (as of 2012:Q1). Figure 2B shows the following: (i) the significantly larger increases in housing prices during the boom period and the general decline in house prices subsequently, (ii) the faster pace of housing price increases relative to the core inflation PCE index during the boom, and (iii) the faster pace of the core inflation PCE index relative to the pace of housing price changes during the subsequent period. In nominal terms, housing prices increased 83 percent during the boom period and declined 18 percent during the bust period. The overall housing price increase was 49 percent.

The view changes slightly when housing prices are expressed in inflation-adjusted terms. Using the core inflation PCE index (see Figure 2B), housing prices increased 57 percent during the boom period and decreased 26 percent during the bust period. The overall housing price increase was 16 percent.

Thus, despite the fact that the S\&P/Case-Shiller index showed a larger boom and a larger bust than the FHFA purchase-only index, the two indexes are remarkably similar when the beginning of the boom is compared with the present. ${ }^{-}$To date, the increase in inflation-adjusted housing prices is virtually identical: 14 percent using the S\&P/Case-Shiller index and 16 percent using the FHFA Purchase-Only index.

The aggregate market values of homes using the two indexes are also roughly similar at the beginning of the boom compared with their most recent values. For example, using the S\&P/ Case-Shiller index, Davis and co-authors $(2007,2008)$ estimate an aggregate market value of homes of $\$ 10.9$ trillion for 1998:Q1; using the FHFA housing price index, they estimate a value of $\$ 11.4$ trillion. ${ }^{-}$Using the most recent estimates for 2012:Q1, the respective estimates are $\$ 19.5$ trillion and $\$ 20.8$ trillion. As suggested above by the differences in percentage changes during the boom period, the estimates for 2006:Q2 differ substantially, with an estimate of \$28.4 trillion based on the S\&P/Case-Shiller index and \$24.9 trillion based on the FHFA index. 


\section{Figure 2A}

FHFA House Price Index (1991:Q1-2012:Q1)

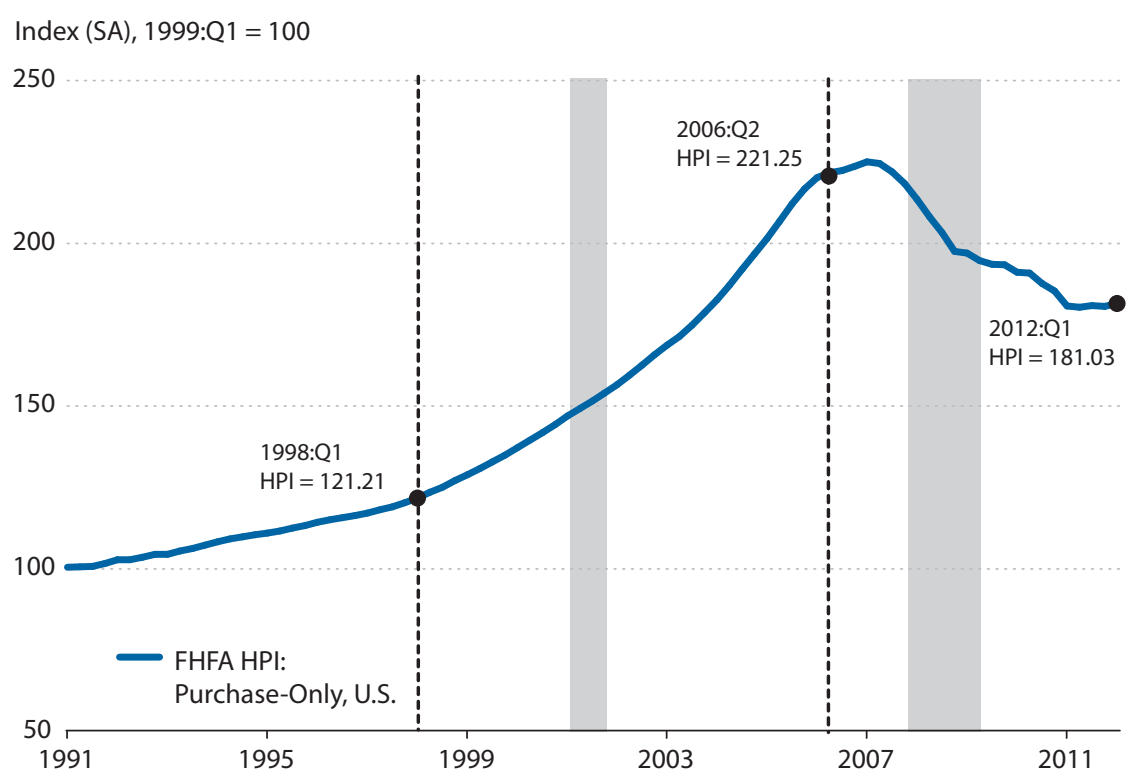

NOTE: The shaded areas indicate U.S. recessions. HPI, house price index; SA, seasonally adjusted.

\section{Figure 2B}

\section{Core PCE Rate and Year-Over-Year Changes in the FHFA HPI (1991:Q1-2012:Q1)}

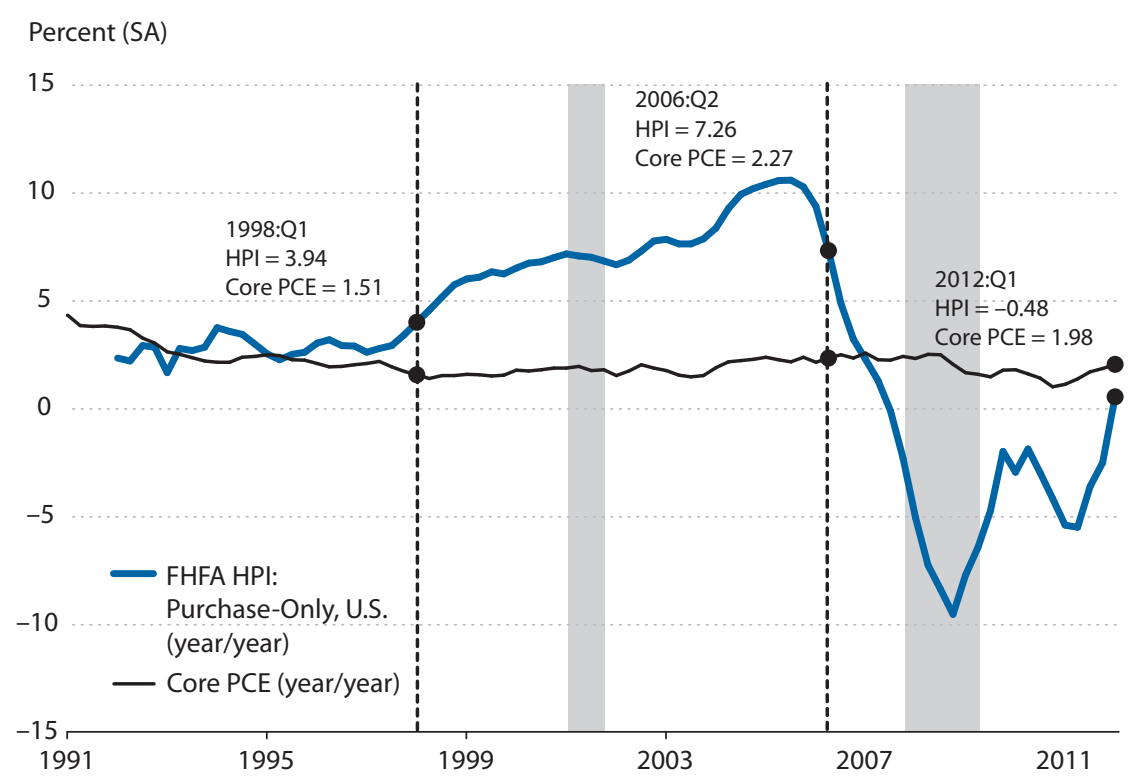

NOTE: The shaded areas indicate U.S. recessions. HPI, house price index; SA, seasonally adjusted. 


\section{Figure 3}

\section{CoreLogic House Price Indexes (1991:Q1-2012:Q1)}

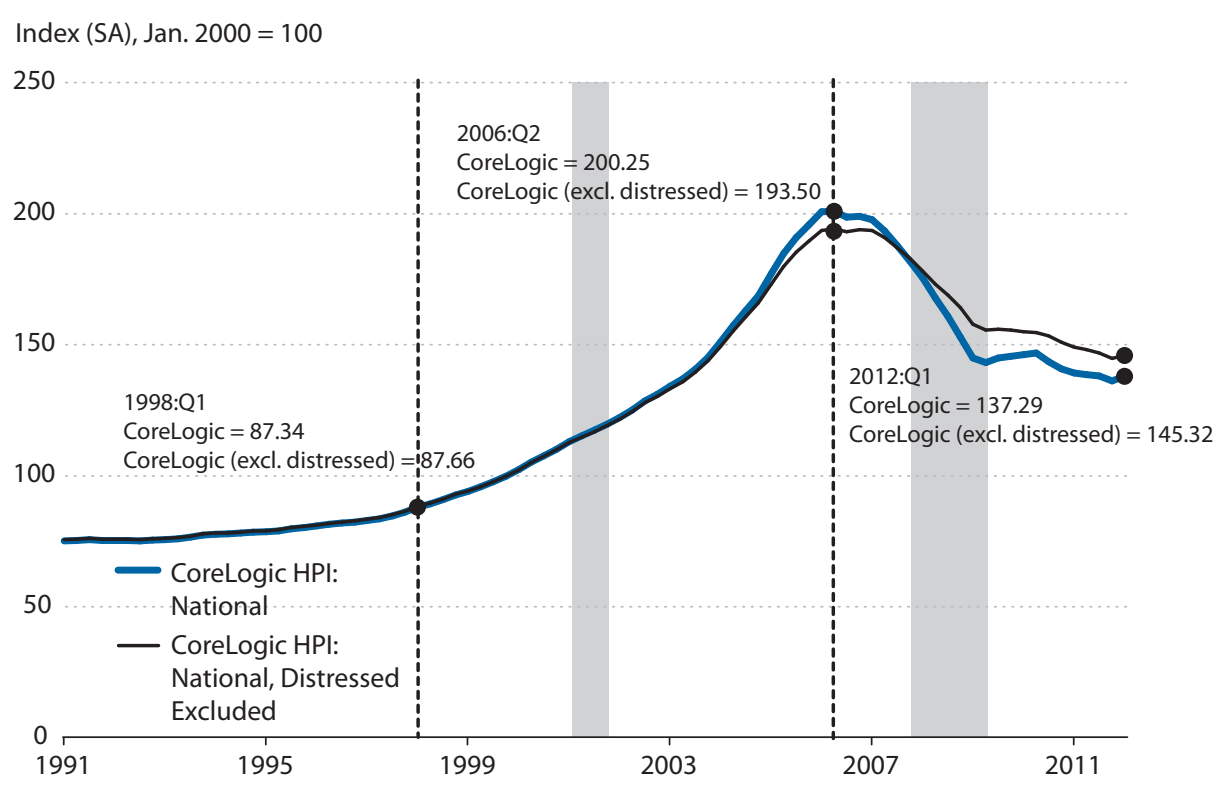

NOTE: The shaded areas indicate U.S. recessions. HPI, house price index; SA, seasonally adjusted.

\section{Distressed Sales and House Prices}

A key development during the bust was a large increase in "distressed sales." Distressed sales are composed primarily of "short sales" and "REOs." Short sales result from a decline in housing prices, which leaves many homeowners with mortgage debts larger than the value of their homes ("underwater"). 9 When these houses are sold, the proceeds fall "short" of the balance owed on the property's loan. Meanwhile, REOs are real estate properties that are owned by the lender rather than the borrower and are frequently acquired through a foreclosure. For various reasons, such as poor maintenance and vandalism, the downward price pressures on distressed sales tend to be larger than on other sales. Such sales also have a negative impact on the values of nearby homes. $\frac{10}{}$

Figure 3 shows two CoreLogic national house price indexes: one that includes distressed sales and one that excludes distressed sales. Distressed sales accounted for roughly 4 percent of sales at the beginning of the boom. During the boom, distressed sales ranged from 3.5 to 16.5 percent of total sales; during the bust, the share of distressed sales ranged from 12.2 to 48 percent and frequently exceeded 30 percent.

Until shortly before the beginning of the bust, the two indexes were virtually indistinguishable from each other. During the boom period, the index including distressed sales showed a nominal increase of 129 percent, while the index excluding distressed sales showed a slightly smaller increase of 121 percent. Thus, the index including the distressed sales rose slightly more than the index excluding distressed sales. During the bust period, when distressed sales repre- 
sented a relatively much larger share of sales than during the boom period, the decline in housing prices including distressed sales was relatively much larger-falling 31 percent-than the 25 percent decline in housing prices excluding distressed sales.

\section{Housing Prices: Structure Versus Land}

As stated earlier, a house consists of two components, a physical structure that can be reproduced and a nonreproducible plot of land. As such, the value of land is the capitalized market value of a home's location. Davis and Heathcote's (2007) seminal contribution to the study of housing prices constructed the first constant-quality price and quantity indexes for the aggregate stock of residential land in the United States. $\frac{11}{}$ Rather than repeat the details of their estimation process, we focus on using their estimates of land values, structure values, and housing prices. $\frac{12}{}$

Figure 4 shows estimates by Davis and Heathcote (2007) using the national S\&P/CaseShiller home price index. The nominal value of homes (thick blue line) is the sum of the value of structures (thin blue line) and the value of residential land (black line). The figure shows that the run-up in housing values from $\$ 10.9$ trillion to $\$ 28.4$ trillion (160 percent) during the boom period was driven by price increases in both structures ( 97 percent) and land (305 percent), but the increase was influenced relatively more so by rapid increases in land values. This latter point is highlighted in Figure 4B, which shows that the relative land share of housing value increased from 30 percent as of 1998:Q1 to 47 percent as of 2006:Q2. Subsequently, as a result of an increase in the value of structures ( 3 percent) and a decline in the value of land ( 69 percent), the relative land share of housing has declined to 21 percent (as of 2012:Q1). One implication, examined more thoroughly later, is that the boom and bust in housing prices is, to a large extent, a boom and bust in residential land prices.

A similar pattern of changes is shown in Figure 5, which uses the FHFA housing price index. This figure indicates that the run-up in housing values from $\$ 11.4$ trillion to $\$ 24.9$ trillion (118 percent) during the boom period was driven by increases in the value of both structures ( 97 percent) and land (161 percent). The relatively rapid increase in land values is highlighted in Figure 5B, where the relative land share of housing value increased from 33 percent as of 1998:Q1 to 40 percent as of 2006:Q2. Subsequently, as a result of an increase in the value of structures (3 percent) and a decline in the value of land ( 45 percent), the relative land share of housing has declined to 26 percent (as of 2012:Q1).

\section{A METROPOLITAN VIEW}

Next we focus on the changes in housing prices in specific real estate markets during the national boom and bust. Our examination of housing prices at the level of metropolitan areas relies on two data sources: S\&P/Case-Shiller indexes and Davis and co-authors $(2007,2008)$.

\section{Across Metropolitan Areas}

We begin by examining the 19 metropolitan areas in the S\&P/Case-Shiller 20-City Composite home price index that include data for the entire period. $\frac{13}{}$ Table 1 summarizes the changes for these 19 areas for the boom and bust periods individually as well as the combined period. 


\section{Cohen, Coughlin, Lopez}

\section{Figure 4A}

Aggregate U.S. Home, Land, and Structure Values (S\&P/Case-Shiller Index, 1975:Q1-2012:Q1)

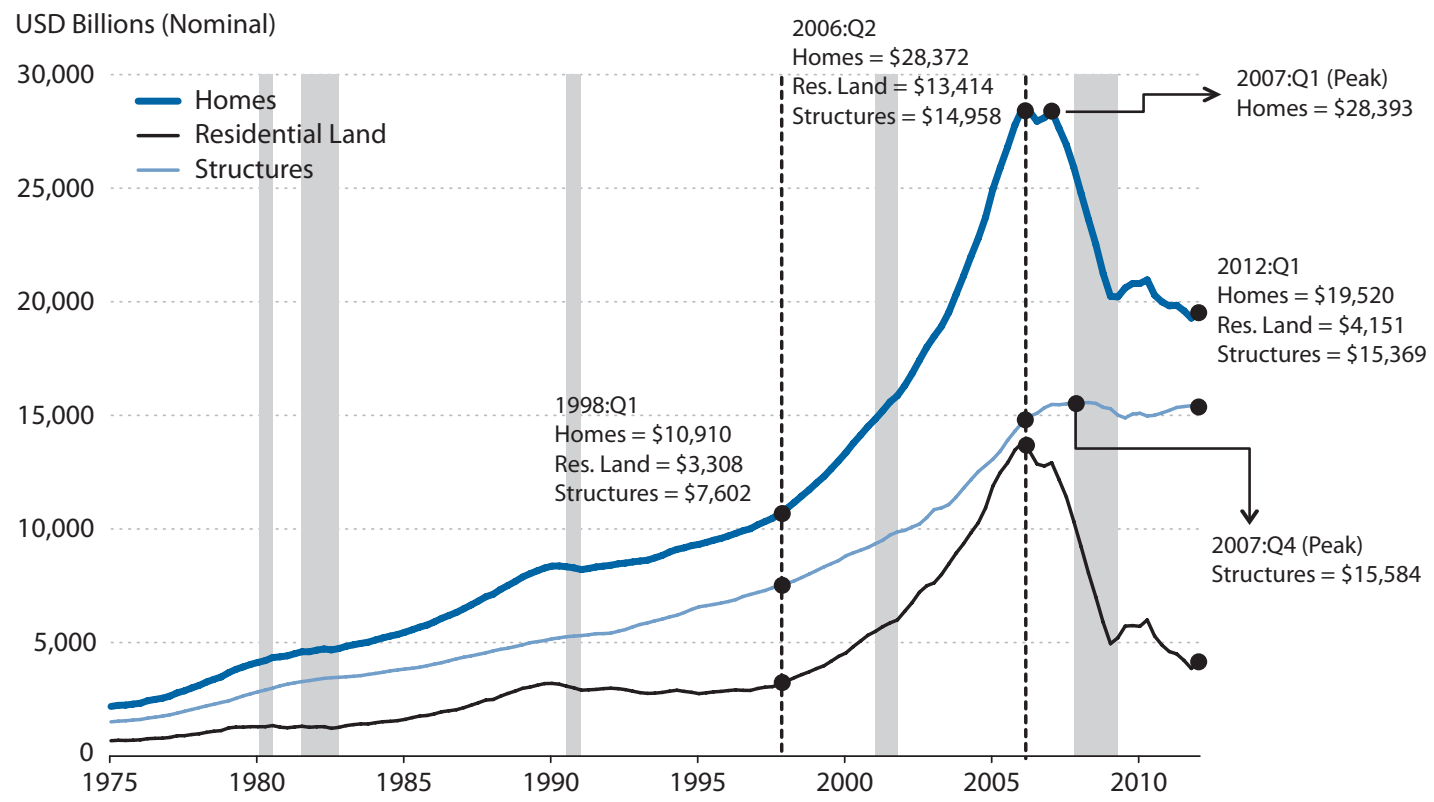

NOTE: The shaded areas indicate U.S. recessions.

\section{Figure 4B}

\section{U.S. Land and Structure Shares (S\&P/Case-Shiller Index, 1975:Q1-2012:Q1)}

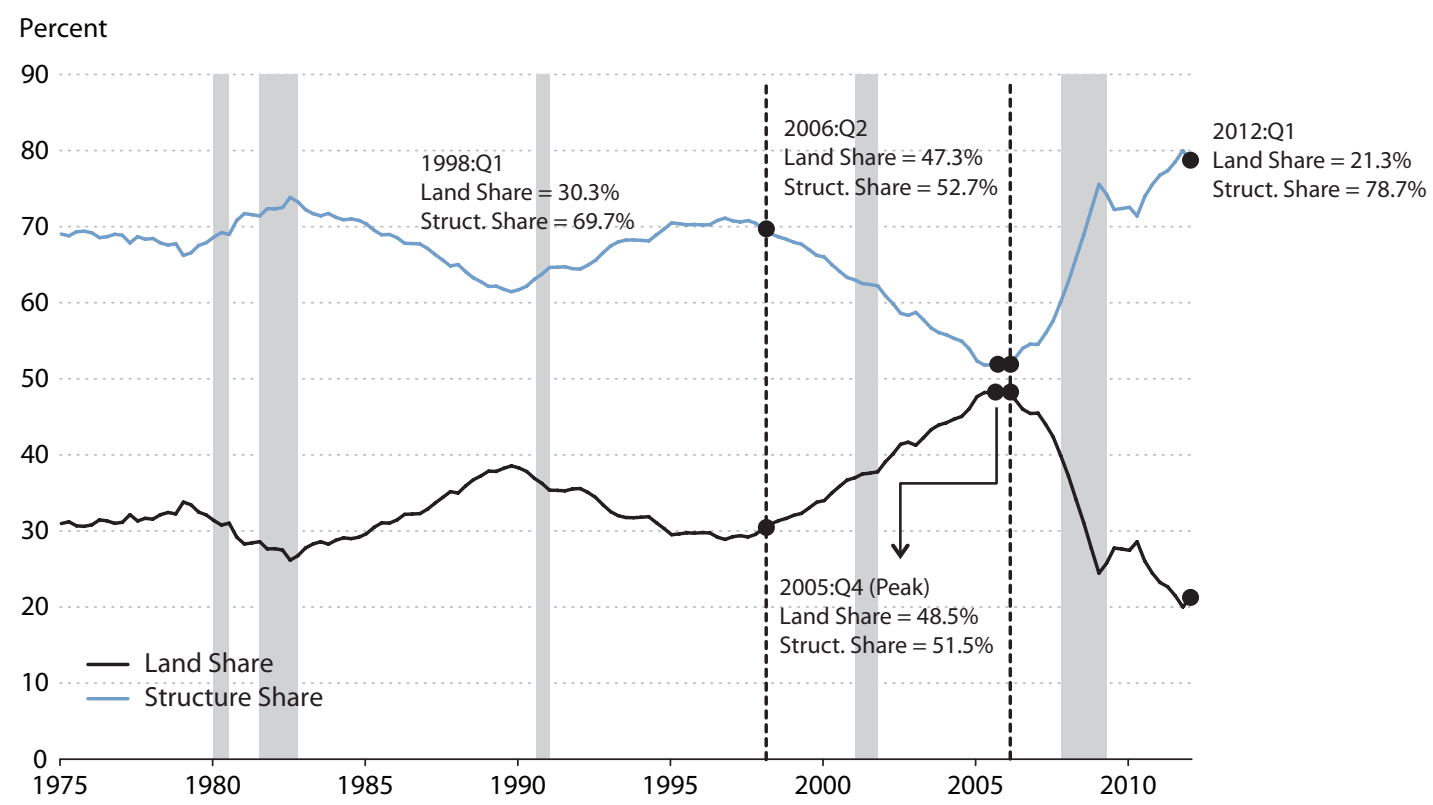

NOTE: The shaded areas indicate U.S. recessions. 


\section{Figure 5A}

Aggregate U.S. Home, Land, and Structure Values (FHFA Index, 1975:Q1-2012:Q1)

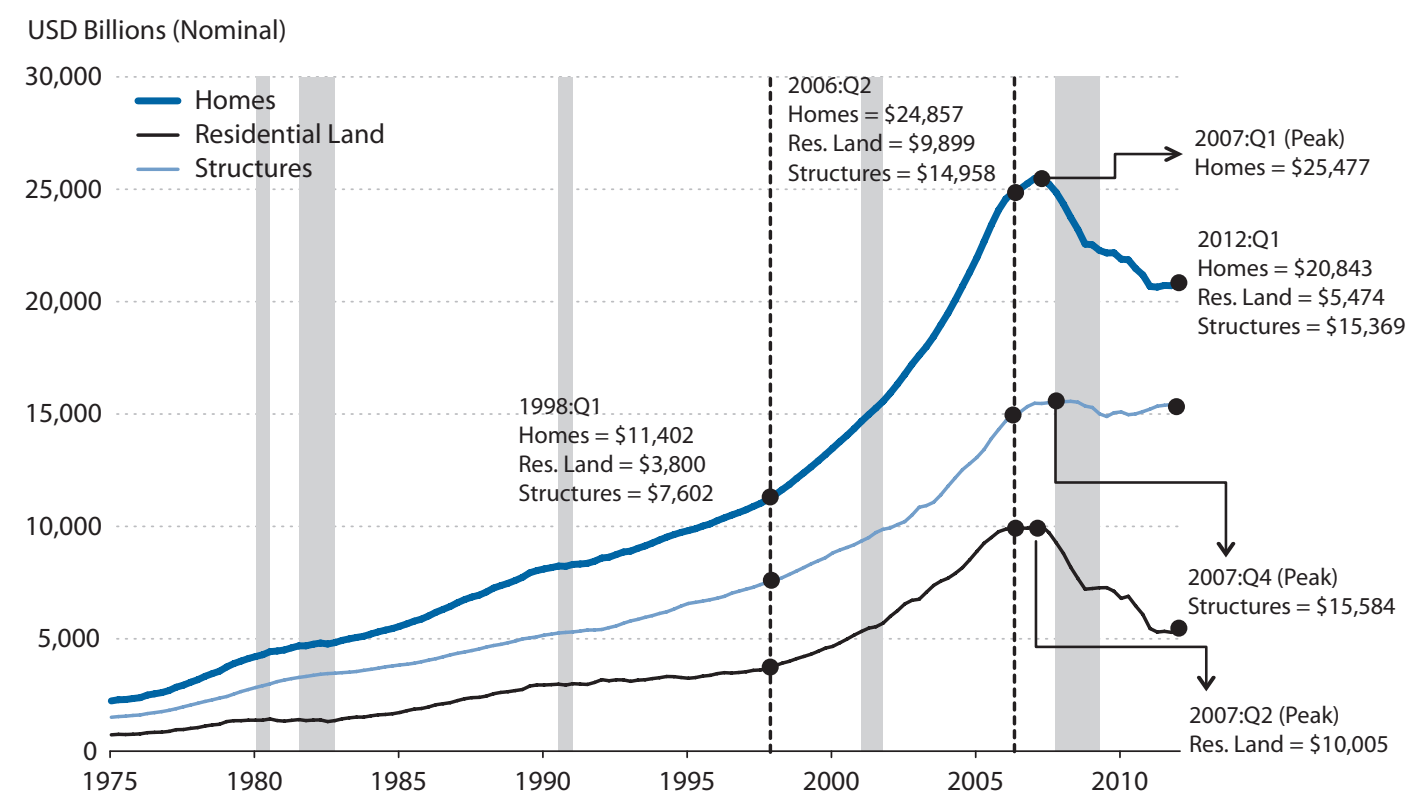

NOTE: The shaded areas indicate U.S. recessions.

\section{Figure 5B}

\section{U.S. Land and Structure Shares (FHFA Index, 1975:Q1-2012:Q1)}

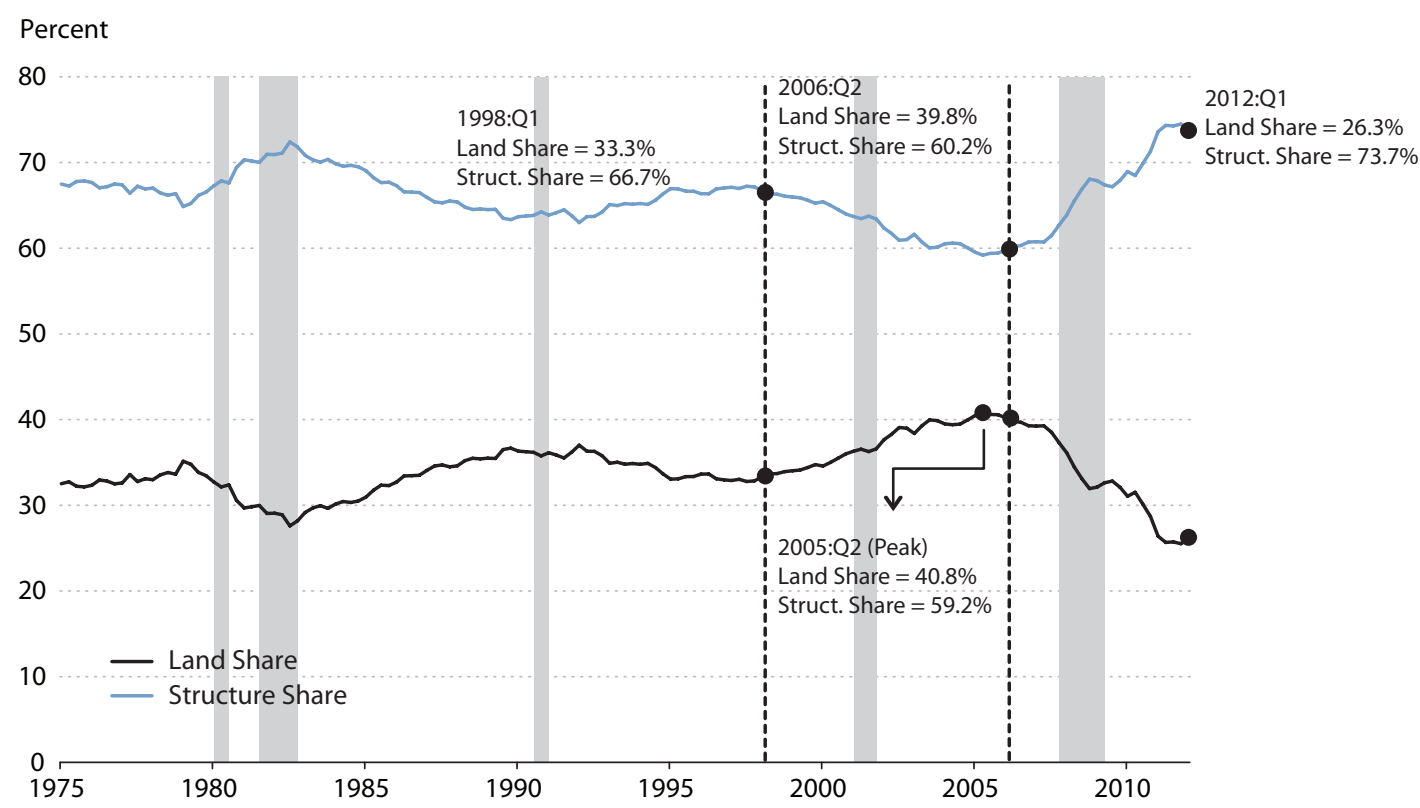

NOTE: The shaded areas indicate U.S. recessions. 


\section{Table 1}

Percent Change in House Prices across Metropolitan Areas

\begin{tabular}{|c|c|c|c|c|c|c|c|}
\hline \multirow{3}{*}{$\frac{\text { Area }}{\text { Atlanta }}$} & \multicolumn{3}{|c|}{$\begin{array}{c}\text { Percent Change, } \\
\text { Nominal House Price Index Values }\end{array}$} & \multicolumn{4}{|c|}{$\begin{array}{c}\text { Percent Change, } \\
\text { Real House Price Index Values }\end{array}$} \\
\hline & $\begin{array}{c}\text { Boom } \\
\text { (1998:Q1-2006:Q2) }\end{array}$ & $\begin{array}{c}\text { Bust } \\
(2006: Q 2-2012: Q 1)\end{array}$ & $\begin{array}{c}\text { Overall } \\
(1998: Q 1-2012: Q 1)\end{array}$ & $\begin{array}{c}\text { Boom } \\
(1998: Q 1-2006: Q 2)\end{array}$ & $\begin{array}{c}\text { Bust } \\
(2006: Q 2-2012: Q 1)\end{array}$ & \multicolumn{2}{|c|}{$\begin{array}{c}\text { Overall } \\
\text { (1998:Q1-2012:Q1) }\end{array}$} \\
\hline & $51.0 \quad(16)$ & -35.4 & $-2.4 \quad(17)$ & $29.9 \quad(16)$ & -41.7 & -24.3 & (17) \\
\hline Boston & $121.1 \quad(10)$ & $-15.9 \quad(17)$ & 85.9 & $90.2 \quad(10)$ & $-24.2 \quad(17)$ & 44.2 & (5) \\
\hline Charlotte & $34.2 \quad(18)$ & $-11.4 \quad$ (18) & $18.9 \quad(15)$ & $15.5 \quad(18)$ & $-20.1 \quad(18)$ & -7.8 & (15) \\
\hline Chicago & $85.1 \quad(14)$ & $-35.3 \quad(10)$ & $19.8 \quad(14)$ & $59.3 \quad(14)$ & $-41.7 \quad(10)$ & -7.1 & (14) \\
\hline Cleveland & $33.3 \quad(19)$ & $-20.1 \quad(16)$ & $6.5 \quad(16)$ & $14.7 \quad(19)$ & $-27.9(16)$ & -17.4 & (16) \\
\hline Denver & $71.3 \quad(15)$ & $-9.2 \quad(19)$ & 55.5 & $47.4 \quad(15)$ & -18.1 (19) & 20.7 & (7) \\
\hline Detroit & $45.9 \quad(17)$ & -43.8 & $-18.0 \quad$ (19) & $25.5 \quad(17)$ & $-49.3 \quad(5)$ & -36.4 & (19) \\
\hline Las Vegas & 150.3 & -61.5 & $-3.7 \quad(18)$ & 115.4 & $-65.3 \quad(1)$ & -25.3 & (18) \\
\hline Los Angeles & 231.5 & -40.6 & 96.9 & 185.2 & $-46.4 \quad(7)$ & 52.8 & $(2)$ \\
\hline Miami & 206.8 & -49.7 & 54.4 & 164.0 & -54.6 & 19.7 & (9) \\
\hline Minneapolis & 107.2 & $-34.2 \quad(11)$ & $36.3 \quad(12)$ & $78.3 \quad(11)$ & $-40.7(11)$ & 5.8 & $(12)$ \\
\hline New York & 156.5 & $-25.6 \quad(13)$ & 90.7 & 120.7 & $-32.9(13)$ & 48.0 & (3) \\
\hline Phoenix & 160.8 & -53.6 & $21.1 \quad(13)$ & 124.4 & -58.1 & -6.0 & (13) \\
\hline Portland & $86.1 \quad(13)$ & $-24.6 \quad(14)$ & $40.2 \quad(10)$ & $60.1 \quad(13)$ & $-32.0(14)$ & 8.8 & $(10)$ \\
\hline San Diego & 212.2 & -39.4 & 89.3 & 168.6 & -45.3 & 46.9 & (4) \\
\hline San Francisco & o 180.2 & -40.7 & 66.2 & 141.1 & $-46.5 \quad(6)$ & 28.9 & (6) \\
\hline Seattle & $104.5 \quad(12)$ & $-24.0 \quad(15)$ & 55.5 & $76.0 \quad(12)$ & $-31.4(15)$ & 20.6 & (8) \\
\hline Tampa & 161.7 & -46.9 & $38.9 \quad(11)$ & 125.2 & -52.1 & 7.8 & (11) \\
\hline Wash., D.C. & 178.1 & $-28.3 \quad(12)$ & 99.4 & 139.3 & $-35.3(12)$ & 54.7 & (1) \\
\hline \multicolumn{8}{|c|}{$\begin{array}{l}\text { NOTE: Nominal values of the S\&P/Case-Shiller house price index series were deflated using the Bureau of Economic Analysis (BEA)'s core PCE } \\
\text { price index. These real values were obtained by first reindexing Haver Analytics' core PCE and nominal S\&P/Case-Shiller series for each metro- } \\
\text { politan area to } 100 \text { at 2000:Q1, and then dividing the reindexed S\&P Case-Shiller series with the reindexed core PCE series. The numbers in } \\
\text { parentheses indicate the rank within the } 19 \text { metropolitan areas. During both the boom period and the entire period, the metropolitan area } \\
\text { with the largest increase is ranked 1, while the area with the smallest increase is ranked 19. During the bust period, the metropolitan area with } \\
\text { the largest (absolute) decrease is ranked 1, while the area with the smallest (absolute) decrease is ranked } 19 \text {. }\end{array}$} \\
\hline
\end{tabular}

The metropolitan areas vary greatly in terms of the percentage changes in housing prices. For example, during the boom period, nominal housing prices more than tripled (i.e., increased more than 200 percent) in three areas: Los Angeles (232 percent), San Diego (212 percent), and Miami (207 percent). Meanwhile, housing prices increased by less than 50 percent in Cleveland (33 percent), Charlotte (34 percent), and Detroit (46 percent). $\stackrel{14}{ }$ To provide some perspective, assume two houses, each valued at $\$ 100,000$, in Cleveland and Los Angeles at the beginning of the housing boom. $\frac{15}{}$ At the end of the national boom, the value of the house in Cleveland would be $\$ 133,000$, while the value of the house in Los Angeles would be $\$ 332,000$, roughly a $\$ 200,000$ difference. $\underline{16}$

Similarly, the declines in housing prices during the bust period vary greatly. For example, the three cities with the largest percentage declines-Las Vegas (-62 percent), Phoenix (-54 percent), and Miami (-50 percent)—experienced housing price declines of at least 50 percent, 
while the four cities with the smallest declines-Denver ( -9 percent), Charlotte ( -11 percent), Boston ( -16 percent), and Cleveland ( -20 percent) - experienced declines of 20 percent or less. To provide some perspective, assume two houses, each valued at $\$ 200,000$, in Las Vegas and Denver at the beginning of the national bust. At the end of the period, the value of the house in Las Vegas would be $\$ 76,000$, while the value of the house in Denver would be $\$ 182,000$, roughly a $\$ 100,000$ difference.

The variation carries over to the changes over the entire period for the metropolitan areas. For example, three areas-Detroit ( -18 percent), Las Vegas ( -4 percent), and Atlanta ( -2 percent) - experienced overall declines for the entire period, while in three other areas-Washington, D.C. (99 percent), Los Angeles (97 percent), and New York (91 percent) - housing prices nearly doubled over the period. As a result, the hypothetical $\$ 100,000$ house at the beginning of the boom would be valued at $\$ 82,000$ in Detroit and $\$ 199,000$ in Washington, D.C.

The disparity across metropolitan areas remains when adjusted for inflation, but the increases during the boom are much smaller and the decreases during the bust are much larger in absolute terms. For example, during the boom, the real increases in Los Angeles, San Diego, and Miami are 185 percent, 169 percent, and 164 percent, respectively, compared with the nominal increases of 232 percent, 212 percent, and 207 percent. During the bust, the real decreases in Las Vegas, Phoenix, and Miami are 65 percent, 58 percent, and 55 percent, respectively, rather than the nominal decreases of 62 percent, 54 percent, and 50 percent.

After adjusting for inflation, seven metropolitan areas have experienced housing price declines for the entire period. In addition to Detroit ( -36 percent) and Las Vegas ( -25 percent), Atlanta ( -24 percent), Cleveland ( -17 percent), Charlotte ( -8 percent), Chicago ( -7 percent), and Phoenix (-6 percent) also experienced declines in real housing prices. Overall, two metropolitan areas experienced real housing price increases of more than 50 percent: Washington, D.C. (55 percent) and Los Angeles (53 percent).

To explore potential relationships across the periods for the metropolitan areas, we calculated simple rank correlation coefficients. The range of this statistic is from -1 to +1 . When comparing two sets of ranks, values close to $-1(+1)$ indicate that metropolitan areas ranked higher in one

period tend to be ranked lower (higher) in the second period, while a value near 0 indicates little or no association. First, we find that the rank correlation between the boom and bust periods is 0.53. $\frac{17}{}$ Thus, metropolitan areas with the larger booms tended to have larger busts. Second, we find a rank correlation of 0.68 between the boom period and overall. This result suggests that metropolitan areas with the largest booms tended to maintain their rank for the period overall. Third, we find a rank correlation of -0.22 between the bust period and overall. This suggests that metropolitan areas with the largest busts tended to have smaller overall changes; however, in contrast to the two other rank correlations, this rank correlation is not statistically significant.

\section{Within Metros, Across Tiers and Across Metros, Within Tiers}

Here we examine the 16 metropolitan areas in the S\&P/Case-Shiller 20-City Composite home price index that include data for the entire period. Table 2 summarizes the percentage changes in housing prices within these areas across housing price tiers. These tiers are constructed so the same number of sales occur in each of the three tiers for a given time period. Then, each repeat-sale pair is assigned to one of the three tiers depending on the first sale price. 


\section{Cohen, Coughlin, Lopez}

\section{Table 2}

Percent Change in Nominal House Prices across Tiers within Metropolitan Areas

\begin{tabular}{|c|c|c|c|}
\hline \multirow[b]{2}{*}{ Area } & \multicolumn{3}{|c|}{ Percent change } \\
\hline & Boom (1998:Q1-2006:Q2) & Bust (2006:Q2-2012:Q1) & Overall (1998:Q1-2012:Q1) \\
\hline \multicolumn{4}{|l|}{ Atlanta } \\
\hline Low tier & 61.0 & $-63.9(1)$ & $-41.9 \quad(3)$ \\
\hline Middle tier & $46.0 \quad(3)$ & $-41.6 \quad(2)$ & $-14.7 \quad(2)$ \\
\hline High tier & $51.2 \quad(2)$ & $-26.3 \quad(3)$ & $11.4 \quad(1)$ \\
\hline \multicolumn{4}{|l|}{ Boston } \\
\hline Low tier & $184.6 \quad(1)$ & $-28.2(1)$ & $104.3 \quad(1)$ \\
\hline Middle tier & 129.2 & $-19.4 \quad(2)$ & $84.8 \quad(2)$ \\
\hline High tier & $98.3 \quad(3)$ & $-9.7 \quad(3)$ & $79.0 \quad(3)$ \\
\hline \multicolumn{4}{|l|}{ Chicago } \\
\hline Low tier & $96.1 \quad(1)$ & $-53.6(1)$ & $-9.1 \quad(3)$ \\
\hline Middle tier & $90.3 \quad(2)$ & $-40.7 \quad(2)$ & $12.9 \quad(2)$ \\
\hline High tier & $76.5 \quad(3)$ & $-28.8 \quad(3)$ & $25.7 \quad(1)$ \\
\hline \multicolumn{4}{|l|}{ Denver } \\
\hline Low tier & $76.9 \quad(1)$ & $-15.2 \quad(1)$ & 50.0 \\
\hline Middle tier & $67.6 \quad(3)$ & $-7.3 \quad(3)$ & $55.3 \quad(1)$ \\
\hline High tier & $70.2 \quad(2)$ & $-8.9 \quad(2)$ & $55.0 \quad(2)$ \\
\hline \multicolumn{4}{|l|}{ Las Vegas } \\
\hline Low tier & $164.2 \quad(1)$ & $-70.0 \quad(1)$ & $-20.6 \quad(3)$ \\
\hline Middle tier & $148.4 \quad(2)$ & $-63.0(2)$ & $-8.1 \quad(2)$ \\
\hline High tier & $142.7 \quad(3)$ & -57.5 & $3.3 \quad(1)$ \\
\hline \multicolumn{4}{|l|}{ Los Angeles } \\
\hline Low tier & 316.9 & $-53.5 \quad(1)$ & $94.0 \quad(3)$ \\
\hline Middle tier & $248.1 \quad(2)$ & $-41.6 \quad(2)$ & $103.4 \quad(1)$ \\
\hline High tier & 188.0 & $-31.6 \quad(3)$ & $97.1 \quad(2)$ \\
\hline \multicolumn{4}{|l|}{ Miami } \\
\hline Low tier & $264.9 \quad(1)$ & $-65.2(1)$ & $27.0 \quad(3)$ \\
\hline Middle tier & $215.4 \quad(2)$ & $-53.8 \quad(2)$ & $45.9 \quad(2)$ \\
\hline High tier & 184.0 & $-43.2 \quad(3)$ & $61.4 \quad(1)$ \\
\hline \multicolumn{4}{|l|}{ Minneapolis } \\
\hline Low tier & $144.3 \quad(1)$ & -48.0 & 27.0 \\
\hline Middle tier & $103.5 \quad(2)$ & $-35.2 \quad(2)$ & $31.8 \quad(2)$ \\
\hline High tier & $93.6 \quad(3)$ & -29.0 & $37.5 \quad(1)$ \\
\hline
\end{tabular}


Table 2, cont'd

Percent Change in Nominal House Prices across Tiers within Metropolitan Areas

\begin{tabular}{|c|c|c|c|}
\hline \multirow[b]{2}{*}{ Area } & \multicolumn{3}{|c|}{ Percent change } \\
\hline & Boom (1998:Q1-2006:Q2) & Bust (2006:Q2-2012:Q1) & Overall (1998:Q1-2012:Q1) \\
\hline \multicolumn{4}{|l|}{ New York } \\
\hline Low tier & 206.5 & $-34.2 \quad(1)$ & $101.5 \quad(1)$ \\
\hline Middle tier & $168.2 \quad(2)$ & $-27.8 \quad(2)$ & $93.6 \quad(2)$ \\
\hline High tier & 128.9 & $-19.7 \quad(3)$ & $83.8 \quad(3)$ \\
\hline \multicolumn{4}{|l|}{ Phoenix } \\
\hline Low tier & $182.5 \quad(1)$ & -65.0 & -1.2 \\
\hline Middle tier & 150.9 & $-56.3 \quad(2)$ & $9.6 \quad(2)$ \\
\hline High tier & $157.3 \quad(2)$ & $-48.2 \quad(3)$ & $33.3 \quad(1)$ \\
\hline \multicolumn{4}{|l|}{ Portland } \\
\hline Low tier & $98.8 \quad(1)$ & $-27.9 \quad(1)$ & $43.3 \quad(1)$ \\
\hline Middle tier & $87.3 \quad(2)$ & $-24.9 \quad(2)$ & $40.7 \quad(2)$ \\
\hline High tier & $79.9 \quad(3)$ & $-23.2 \quad(3)$ & $38.1 \quad(3)$ \\
\hline \multicolumn{4}{|l|}{ San Diego } \\
\hline Low tier & $281.5 \quad(1)$ & $-48.5 \quad(1)$ & $96.6(1)$ \\
\hline Middle tier & 216.0 & $-39.7 \quad(2)$ & $90.5 \quad(2)$ \\
\hline High tier & 177.4 & $-33.1 \quad(3)$ & $85.7 \quad(3)$ \\
\hline \multicolumn{4}{|l|}{ San Francisco } \\
\hline Low tier & $268.3 \quad(1)$ & $-59.9(1)$ & $47.5 \quad(3)$ \\
\hline Middle tier & $187.1 \quad(2)$ & $-41.3 \quad(2)$ & $68.7 \quad(2)$ \\
\hline High tier & $138.2 \quad(3)$ & $-24.2 \quad(3)$ & $80.6 \quad(1)$ \\
\hline \multicolumn{4}{|l|}{ Seattle } \\
\hline Low tier & $118.2 \quad(1)$ & $-36.2(1)$ & 39.2 \\
\hline Middle tier & $107.4 \quad(2)$ & $-27.4 \quad(2)$ & $50.6 \quad(2)$ \\
\hline High tier & $96.7 \quad(3)$ & $-18.8 \quad(3)$ & $59.7 \quad(1)$ \\
\hline \multicolumn{4}{|l|}{ Tampa } \\
\hline Low tier & $212.5 \quad(1)$ & $-60.9 \quad(1)$ & 22.2 \\
\hline Middle tier & 172.6 & $-51.9 \quad(2)$ & $31.2 \quad(2)$ \\
\hline High tier & $142.6 \quad(3)$ & $-41.6 \quad(3)$ & $41.7 \quad(1)$ \\
\hline \multicolumn{4}{|c|}{ Washington, D.C. } \\
\hline Low tier & $214.6 \quad(1)$ & $-42.8 \quad(1)$ & 80.0 \\
\hline Middle tier & $182.7 \quad(2)$ & $-31.6 \quad(2)$ & $93.4 \quad(2)$ \\
\hline High tier & 151.5 & $-18.6 \quad(3)$ & 104.8 \\
\hline
\end{tabular}




\section{Cohen, Coughlin, Lopez}

Table 3

Percent Change in Nominal House Prices across Metropolitan Areas within Tiers

\begin{tabular}{|c|c|c|c|}
\hline \multirow[b]{2}{*}{ Tier } & \multicolumn{3}{|c|}{ Percent change } \\
\hline & Boom (1998:Q1-2006:Q2) & Bust (2006:Q2-2012:Q1) & Overall (1998:Q1-2012:Q1) \\
\hline \multicolumn{4}{|l|}{ Low tier } \\
\hline Atlanta & $61.0 \quad(16)$ & $-63.9 \quad(4)$ & $-41.9(16)$ \\
\hline Boston & $184.6 \quad(8)$ & $-28.2(14)$ & $104.3 \quad(1)$ \\
\hline Chicago & $96.1 \quad(14)$ & $-53.6 \quad(7)$ & $-9.1 \quad(14)$ \\
\hline Denver & $76.9 \quad(15)$ & $-15.2(16)$ & $50.0 \quad(6)$ \\
\hline Las Vegas & $164.2(10)$ & $-70.0 \quad(1)$ & $-20.6(15)$ \\
\hline Los Angeles & $316.9 \quad(1)$ & $-53.5 \quad(8)$ & $94.0 \quad(4)$ \\
\hline Miami & $264.9 \quad(4)$ & $-65.2 \quad(2)$ & $27.0 \quad(10)$ \\
\hline Minneapolis & $144.3(11)$ & $-48.0(10)$ & $27.0 \quad(11)$ \\
\hline New York & $206.5 \quad(7)$ & $-34.2(13)$ & $101.5 \quad(2)$ \\
\hline Phoenix & $182.5 \quad(9)$ & $-65.0 \quad(3)$ & $-1.2 \quad(13)$ \\
\hline Portland & $98.8 \quad(13)$ & $-27.9(15)$ & $43.3 \quad(8)$ \\
\hline San Diego & $281.5 \quad(2)$ & $-48.5 \quad(9)$ & $96.6 \quad(3)$ \\
\hline San Francisco & $268.3 \quad(3)$ & $-59.9 \quad(6)$ & $47.5 \quad(7)$ \\
\hline Seattle & $118.2(12)$ & $-36.2(12)$ & $39.2 \quad(9)$ \\
\hline Tampa & $212.5 \quad(6)$ & $-60.9 \quad(5)$ & $22.2 \quad(12)$ \\
\hline Washington, D.C. & $214.6 \quad(5)$ & $-42.8(11)$ & $80.0 \quad(5)$ \\
\hline \multicolumn{4}{|l|}{ Middle tier } \\
\hline Atlanta & $46.0 \quad(16)$ & $-41.6 \quad(5)$ & $-14.7(16)$ \\
\hline Boston & $129.2(10)$ & $-19.4(15)$ & $84.8 \quad(5)$ \\
\hline Chicago & $90.3 \quad(13)$ & $-40.7 \quad(8)$ & $12.9 \quad(13)$ \\
\hline Denver & $67.6 \quad(15)$ & $-7.3 \quad(16)$ & $55.3 \quad(7)$ \\
\hline Las Vegas & $148.4 \quad(9)$ & $-63.0 \quad(1)$ & $-8.1 \quad(15)$ \\
\hline Los Angeles & $248.1 \quad(1)$ & $-41.6 \quad(6)$ & 103.4 \\
\hline Miami & 215.4 & $-53.8 \quad(3)$ & 45.9 \\
\hline Minneapolis & $103.5(12)$ & $-35.2(10)$ & $31.8 \quad(11)$ \\
\hline New York & $168.2 \quad(7)$ & $-27.8(12)$ & $93.6 \quad(2)$ \\
\hline Phoenix & 150.9 & $-56.3 \quad(2)$ & $9.6 \quad(14)$ \\
\hline Portland & $87.3 \quad(14)$ & $-24.9(14)$ & $40.7 \quad(10)$ \\
\hline San Diego & $216.0 \quad(2)$ & $-39.7 \quad(9)$ & $90.5 \quad(4)$ \\
\hline San Francisco & $187.1 \quad(4)$ & $-41.3 \quad(7)$ & 68.7 \\
\hline Seattle & $107.4(11)$ & $-27.4(13)$ & $50.6 \quad(8)$ \\
\hline Tampa & $172.6 \quad(6)$ & $-51.9 \quad(4)$ & $31.2 \quad(12)$ \\
\hline Washington, D.C. & $182.7 \quad(5)$ & $-31.6(11)$ & $93.4 \quad(3)$ \\
\hline
\end{tabular}


Cohen, Coughlin, Lopez

\section{Table 3, cont'd}

Percent Change in Nominal House Prices across Metropolitan Areas within Tiers

\begin{tabular}{|c|c|c|c|}
\hline \multirow[b]{2}{*}{ Tier } & \multicolumn{3}{|c|}{ Percent change } \\
\hline & Boom (1998:Q1-2006:Q2) & Bust (2006:Q2-2012:Q1) & Overall (1998:Q1-2012:Q1) \\
\hline \multicolumn{4}{|l|}{ High tier } \\
\hline Atlanta & 51.2 & $-26.3 \quad(9)$ & 11.4 (15) \\
\hline Boston & $98.3 \quad(10)$ & $-9.7 \quad(15)$ & $79.0 \quad(6)$ \\
\hline Chicago & $76.5 \quad(14)$ & $-28.8 \quad(8)$ & $25.7 \quad(14)$ \\
\hline Denver & 70.2 & $-8.9 \quad(16)$ & 55.0 \\
\hline Las Vegas & $142.7 \quad(6)$ & $-57.5 \quad(1)$ & $3.3 \quad(16)$ \\
\hline Los Angeles & 188.0 & $-31.6 \quad(6)$ & $97.1 \quad(2)$ \\
\hline Miami & $184.0 \quad(2)$ & $-43.2 \quad(3)$ & $61.4 \quad(7)$ \\
\hline Minneapolis & $93.6 \quad(12)$ & $-29.0 \quad(7)$ & $37.5 \quad(12)$ \\
\hline New York & $128.9 \quad(9)$ & $-19.7(12)$ & $83.8 \quad(4)$ \\
\hline Phoenix & $157.3 \quad(4)$ & $-48.2 \quad(2)$ & $33.3 \quad(13)$ \\
\hline Portland & $79.9 \quad(13)$ & $-23.2(11)$ & $38.1 \quad(11)$ \\
\hline San Diego & 177.4 & $-33.1 \quad(5)$ & $85.7 \quad(3)$ \\
\hline San Francisco & $138.2 \quad(8)$ & $-24.2(10)$ & $80.6 \quad(5)$ \\
\hline Seattle & $96.7 \quad(11)$ & $-18.8(13)$ & $59.7 \quad(8)$ \\
\hline Tampa & $142.6 \quad(7)$ & $-41.6 \quad(4)$ & $41.7 \quad(10)$ \\
\hline Washington, D.C. & $151.5 \quad(5)$ & $-18.6(14)$ & $104.8 \quad(1)$ \\
\hline
\end{tabular}

In some cases, individual properties may fall into a tier on the first sale that differs from the tier on their repeat sale; however, the tier of the first sale determines the treatment of the paired sale. $\frac{18}{}$

A few regularities can be identified across these 16 metropolitan areas. Without exception during the boom, the low tier showed the largest percentage increase in house prices. $\frac{19}{}$ Meanwhile, the smallest percentage increase nearly always (in 13 of 16 areas) occurred in the high tier. Without exception during the bust, the low tier experienced the largest (absolute) percentage decrease. ${ }^{20}$ Meanwhile, the high tier nearly always (in 15 of 16 areas) showed the smallest (absolute) percentage decrease in house prices. Combining the two periods, the most favorable percentage price changes (in 10 of 16 areas) were generally found in the high tier. On net, in each of these 10 areas the overall change was positive. Meanwhile, the least favorable percentage price changes (in 12 of 16 areas) were generally found in the low tier, with 4 of these 12 cases revealing a decline in nominal housing prices.

We now turn to a comparison across metropolitan areas within tiers, beginning with the low tier during the boom period. This information is summarized in Table 3, which is a reformatting of the data in Table 2. For the low tier, during the boom the percentage increase in housing prices ranged from 61 percent in Atlanta to 317 percent in Los Angeles. San Diego and 


\section{Cohen, Coughlin, Lopez}

San Francisco have the next-largest changes with increases of 281 percent and 268 percent, respectively. During the bust, the percentage changes (i.e., declines) in housing prices ranged from -15 percent in Denver to -70 percent in Las Vegas.

Given these changes during the boom and bust periods, is there any association between them? For example, did areas experiencing the largest percentage increases in low-tier housing prices during the boom experience the largest (absolute) percentage decreases during the bust? To answer this question, we calculate a simple rank correlation coefficient. In the present case, the rank correlation coefficient is 0.21 , which indicates a small, but not statistically significant, association across the two periods.

During the entire period under consideration, large percentage differences occurred in the changes in low-tier housing prices across metropolitan areas. Housing prices more than doubled in Boston (104 percent) and New York (102 percent), while housing prices declined in four cities: Atlanta ( -42 percent), Las Vegas ( -21 percent), Chicago ( -9 percent), and Phoenix ( -1 percent).

For the middle tier, identical to the low tier, housing prices during the boom rose the most in percentage terms in Los Angeles (248 percent) and San Diego (216 percent). Miami was a close third with an increase of 215 percent. Also identical to the low tier, housing prices rose the least in Atlanta (46 percent) and Denver (68 percent). In fact, the rank correlation coefficient using the low and middle tiers during the boom period is 0.98 , indicating a high degree of association. In other words, the ranking of areas from the largest to the smallest in terms of housing price percentage changes is virtually identical for the low and middle tiers.

During the bust period, Denver experienced the smallest decline ( -7 percent), while Las Vegas experienced the largest decline (-63 percent). In fact, the rank correlation coefficient using the low and middle tiers for the bust period is also 0.98 , indicating that the ranking of housing price percentage changes is virtually identical for the low and middle tiers. Meanwhile, the simple rank correlation coefficient using the boom and bust periods for the middle tier is 0.37 , suggesting a positive but statistically insignificant association.

During the entire period under consideration, similar to the low tier, Los Angeles (103 percent) and New York (94 percent) were among the areas with the largest increases for the middle tier. Atlanta ( -15 percent) and Las Vegas ( -8 percent) were the only two middle tier areas with overall declines in housing prices. Comparing the overall changes for the middle tier with those for the low tier yields a rank correlation coefficient of 0.94 , suggesting little difference across tiers in terms of the ranking of housing price changes.

Turning to the high tier, as occurred in the other tiers during the boom period, Los Angeles experienced the largest percentage increase (188 percent). In light of the preceding results, it is not surprising that Miami (184 percent) and San Diego (177 percent) also showed large increases. It is also not surprising that Atlanta (51 percent) and Denver ( 70 percent) showed the smallest increases. The similarity across tiers during the boom period is reflected in the rank correlation coefficients. For the high and low tiers the rank correlation coefficient is 0.88 , while for the high and middle tiers the rank correlation coefficient is 0.93 .

During the bust period for the high tier, Denver experienced the smallest decline ( -9 percent), while Las Vegas experienced the largest decline ( -57 percent). Using the boom and bust periods for the high tier, the rank correlation coefficient is 0.55 , indicating that areas with the largest percentage increases during the boom period tended to have the largest (absolute) per- 


\section{Table 4}

\section{Components of Home Value by Geographic Region}

\begin{tabular}{|c|c|c|c|c|}
\hline \multirow[b]{2}{*}{ Region } & \multicolumn{3}{|c|}{ Component value (\$) } & \multirow[b]{2}{*}{ Land's share of value (\%) } \\
\hline & Home & Structure & Land & \\
\hline \multicolumn{5}{|l|}{ 1998:Q1 } \\
\hline Midwest & 148,169 & 109,388 & 38,781 & 25 \\
\hline Southeast & 147,047 & 93,539 & 53,508 & 35 \\
\hline Southwest & 140,778 & 95,458 & 45,320 & 29 \\
\hline East Coast & 207,709 & 113,200 & 94,509 & 44 \\
\hline West Coast & 294,145 & 108,705 & 185,440 & 58 \\
\hline Full sample & 189,984 & 105,537 & 84,447 & 38 \\
\hline \multicolumn{5}{|l|}{ 2006:Q2 } \\
\hline Midwest & 195,896 & 135,656 & 60,240 & 27 \\
\hline Southeast & 204,030 & 126,733 & 77,297 & 35 \\
\hline Southwest & 205,476 & 122,345 & 83,130 & 34 \\
\hline East Coast & 434,659 & 148,119 & 286,541 & 64 \\
\hline West Coast & 706,972 & 145,988 & 560,984 & 76 \\
\hline Full sample & 356,472 & 136,766 & 219,706 & 47 \\
\hline \multicolumn{5}{|l|}{ 2012:Q1 } \\
\hline Midwest & 138,425 & 130,930 & 7,495 & 5 \\
\hline Southeast & 132,780 & 119,843 & 12,936 & 9 \\
\hline Southwest & 155,990 & 133,846 & 22,145 & 13 \\
\hline East Coast & 286,100 & 166,311 & 119,789 & 39 \\
\hline West Coast & 388,773 & 168,691 & 220,082 & 48 \\
\hline Full sample & 224,564 & 145,427 & 79,138 & 23 \\
\hline
\end{tabular}

centage decreases during the bust. Is there any similarity across tiers during the bust period? Using the high and low tiers, the rank correlation coefficient is 0.85 , while using the high and middle tiers the rank correlation coefficient is 0.90 . Thus, it appears that across areas the tiers behaved similarly.

\section{Across Metropolitan Areas: Land Versus Structure}

The importance of land and structures in determining house values across metropolitan areas can be examined by using data from Davis and co-authors $(2007,2008) .21$ Using additional data, we repeat calculations analogous to those in Davis and Palumbo (2008) and highlight some of the key observations across metropolitan areas during the national boom and bust in housing prices.

Based on Table 4, which shows the inflation-adjusted levels of home values as well as the components of structure and land, and Table 5, which shows the percentage changes in these 
Cohen, Coughlin, Lopez

\section{Table 5}

\section{Change in Components of Home Value by Geographic Region}

\begin{tabular}{|c|c|c|c|c|}
\hline \multirow[b]{2}{*}{ Region } & \multicolumn{3}{|c|}{ Cumulative change in value (\%) } & \multirow{2}{*}{$\begin{array}{l}\text { Change in land's share of value } \\
\text { (percentage points) }\end{array}$} \\
\hline & Home & Structure & Land & \\
\hline \multicolumn{5}{|c|}{ 1998:Q1-2006:Q2 } \\
\hline Midwest & 30 & 24 & 61 & 2.5 \\
\hline Southeast & 42 & 37 & 62 & -0.1 \\
\hline Southwest & 42 & 27 & 79 & 5.3 \\
\hline East Coast & 107 & 32 & 204 & 19.5 \\
\hline West Coast & 141 & 34 & 231 & 17.4 \\
\hline Full sample & 73 & 30 & 130 & 9.3 \\
\hline \multicolumn{5}{|c|}{ 2006:Q2-2012:Q2 } \\
\hline Midwest & -27 & -4 & -80 & -21.8 \\
\hline Southeast & -33 & -4 & -81 & -26.1 \\
\hline Southwest & -18 & 9 & -65 & -21.1 \\
\hline East Coast & -33 & 12 & -59 & -24.4 \\
\hline West Coast & -45 & 15 & -65 & -27.6 \\
\hline Full sample & -31 & 6 & -70 & -23.9 \\
\hline \multicolumn{5}{|c|}{ 1998:Q1-2012:Q1 } \\
\hline Midwest & -6 & 19 & -72 & -19.3 \\
\hline Southeast & -9 & 32 & -79 & -26.1 \\
\hline Southwest & 13 & 39 & -39 & -15.8 \\
\hline East Coast & 36 & 48 & 21 & -4.9 \\
\hline West Coast & 30 & 55 & 3 & -10.1 \\
\hline Full sample & 13 & 38 & -32 & -14.6 \\
\hline
\end{tabular}

NOTE: Nominal values for home, structure, and land values are deflated with the BEA's core PCE index $(2004=100)$. Unweighted averages of the individual percent changes for each MSA are taken across sample cities in each region. A total of $46 \mathrm{MSAs}$ are included in the full sample (see the appendix). The changes in land share percentages were obtained by averaging the individual differences in MSA land share percentages for the two quarters in question.

levels for the boom period, the bust period, and overall, a number of observations are apparent. Table 4 shows that average home values tend to be much higher for metropolitan areas on the East and West Coasts than in the Midwest, Southeast, and Southwest. For example, housing prices during 1998:Q1 for metropolitan areas in the East Coast region were 40 percent higher than in the Midwest, 41 percent higher than in the Southeast, and 48 percent higher than in the Southwest. Meanwhile, housing prices in the West Coast region were roughly double those in the Midwest, Southeast, and Southwest.

We now turn to observations highlighted by Table 5. First, during the boom period, home values increased substantially more in metropolitan areas on the East Coast and West Coast than in metropolitan areas elsewhere. In metropolitan areas on the East Coast and West Coast, real home prices more than doubled, while in metropolitan areas elsewhere (i.e., Midwest, 
Southeast, and Southwest) the increase was less than 50 percent. Second, during the bust, the percentage declines in the metropolitan areas on the East Coast and West Coast were only slightly larger than in other areas. Third, over the entire period (i.e., the beginning of the boom to the present [as of 2012:Q1]) home prices showed substantial increases in the metropolitan areas on the East Coast and West Coast and only small changes elsewhere.

In addition to grouping the metropolitan areas into regions, we also examined patterns in housing price changes across the 46 metropolitan areas. A rank correlation coefficient of 0.74 indicates that metropolitan areas with the largest percentage gains in housing values during the boom also tended to be the areas with the largest percentage declines during the bust. With a rank correlation of 0.69 , the same pattern holds between the boom and overall changes in housing prices. However, no statistically significant relationship was found between the bust and overall changes in housing prices.

Shifting to an examination of the relative importance of changes in land values relative to structure values, a number of observations stand out. First, Table 4 shows that at the beginning of the boom, the land share of a home's total value was substantially larger in metropolitan areas on the East Coast and West Coast than elsewhere. For example, the land share was 44 percent on the East Coast and 58 percent on the West Coast, while it was 25 percent in the Midwest, 35 percent in the Southeast, and 29 percent in the Southwest.

Second, during the boom, the land share of a home's total value rose substantially in metropolitan areas on the East Coast and West Coast, while this share changed minimally elsewhere. Using Table 5 (rounded values), the land share increased 20 percentage points on the East Coast and 17 percentage points on the West Coast, while it increased 2 percentage points in the Midwest, was roughly unchanged in the Southeast, and increased 5 percentage points in the Southwest.

Third, during the bust, the land share of a home's total value declined substantially in metropolitan areas throughout the United States. The average decline was 24 percentage points nationally, ranging from 21 percentage points in metropolitan areas in the Southwest to 28 percentage points in metropolitan areas on the West Coast.

Fourth, the current land share of a home's total value is only marginally lower than it was at the beginning of the boom in metropolitan areas on the East Coast and West Coast, while it is substantially lower elsewhere. For example, the land share is 5 percentage points lower on the East Coast and 10 percentage points lower on the West Coast, while it is 20 percentage points lower in the Midwest, 26 percentage points lower in the Southeast, and 16 percentage points lower in the Southwest. Thus, the land share of a home's total value has remained relatively higher on the East Coast and West Coast than elsewhere in the United States.

Examining the 46 metropolitan areas individually provides additional insights concerning changes in land prices and structure prices across these areas. No statistically significant relationship was found for land price percentage changes using the boom and bust periods. However, metropolitan areas with the largest percentage increases in land prices during the boom also tended to have the largest increases overall, and metropolitan areas with the largest percentage declines during the bust tended to have the smallest increases overall. The rank correlation coefficients were 0.54 and -0.82 , respectively.

The rank correlation of -0.40 for structure prices suggests that metropolitan areas with the largest percentage increases in structure prices during the boom tended to be the areas with the 


\section{Cohen, Coughlin, Lopez}

smallest percentage declines during the bust. In addition, metropolitan areas with the largest percentage increases in structure prices during the boom also tended to have the largest increases overall, and metropolitan areas with the largest percentage declines during the bust tended to have smaller increases overall. The rank correlation coefficients were 0.79 and -0.81 , respectively.

In contrast to Davis and co-authors (2007, 2008), Kuminoff and Pope (2011) estimate the market value of residential structures as opposed to the replacement cost of residential structures. It is certainly possible that these two measures could differ. If so, then the estimates of residential land by these groups of authors would differ as well. In fact, this is what Kuminoff and Pope (2011) find when they compare their annual estimates for 1998-2009 for Miami, San Francisco, Boston, and Charlotte with those of Davis and Palumbo (2008). Kuminoff and Pope (2011) find evidence suggesting that the market values of structures may have exceeded their replacement costs during the boom period. 22 This implies that during the boom period the land shares estimated by Kuminoff and Pope (2011) should tend to be less than those estimated by Davis and Palumbo (2008). $\underline{23}$ Moreover, an implication of Kuminoff and Pope's (2011) study is that changes in the market value of structures played a larger role in home price volatility than implied by Davis and Palumbo (2008). $\underline{24}$

\section{HOUSING PRICES ABROAD: DIFFERENCES AND SIMILARITIES}

To provide a broader geographic perspective, we explore how housing prices in other countries changed during the boom and bust in housing prices in the United States. $\frac{25}{}$ Not surprisingly, we find much diversity across countries; however, the patterns in housing prices for 7 of the 18 countries examined are roughly similar to those in the United States.

Table 6 provides a summary of the experiences of the United States and 18 foreign countries. The price index for each country is consistent with the FHFA quarterly housing price index used previously. For comparability across countries, we use inflation-adjusted housing prices. ${ }^{26}$ The table reports the inflation-adjusted housing prices for each country for the periods used for the U.S. boom and bust. A few facts stand out. First, during the boom, the increase in the United States was not especially large. The U.S. increase ranked 15th among the 19 countries. Second, during the bust, the U.S. decline was relatively large. Only Ireland experienced a larger decline. Third, the rank correlation across countries between the boom and the bust is small (0.22) and is not statistically significant.

Obviously, a specific country's boom and bust need not exactly coincide with the U.S. experience, so the following discussion of similarity/dissimilarity relies on both the actual numbers in the table and an assessment based on the pattern of price changes during recent years. We begin by looking at the countries that did not experience housing price changes similar to those in the United States. These countries fall into one of two categories: First, two countriesGermany and Japan-experienced no boom in housing prices, but rather had a general decline in inflation-adjusted housing prices from 1998 onward. For example, during the boom period, while U.S. prices rose 50 percent, housing prices in Germany and Japan declined 11 percent and 26 percent, respectively. From the beginning of the boom period to the present, German and Japanese prices fell by 16 percent and 32 percent, respectively, while U.S. prices rose by 16 percent. 


\section{Table 6}

\begin{tabular}{|c|c|c|c|c|c|c|c|}
\hline \multirow{2}{*}{$\frac{\text { Country }}{\text { United States }}$} & \multicolumn{2}{|c|}{$\begin{array}{c}\text { Boom } \\
(1998: Q 1-2006: Q 2)\end{array}$} & \multicolumn{2}{|c|}{$\begin{array}{c}\text { Bust } \\
\text { (2006:Q2-2011:Q3) }\end{array}$} & \multicolumn{2}{|c|}{$\begin{array}{c}\text { Overall } \\
\text { (1998:Q1-2011:Q3) }\end{array}$} & \multirow{2}{*}{$\begin{array}{c}\text { Similar to } \\
\text { United States? } \\
-\end{array}$} \\
\hline & 49.9 & (15) & -22.6 & $(2)$ & 16.0 & (16) & \\
\hline Australia & 78.5 & (7) & 17.7 & (17) & 110.1 & (3) & No \\
\hline Belgium & 55.2 & $(11)$ & 12.4 & (14) & 74.4 & (7) & No \\
\hline Canada & 53.3 & (13) & 28.5 & (19) & 96.9 & (4) & No \\
\hline Denmark & 79.5 & (6) & -19.5 & (4) & 44.6 & (13) & Yes \\
\hline Finland & 68.4 & (8) & 2.7 & $(11)$ & 72.9 & (8) & No \\
\hline France & 102.2 & (4) & 5.1 & $(12)$ & 112.6 & $(2)$ & No \\
\hline Germany & -11.4 & (18) & -5.7 & (9) & -16.5 & (18) & No \\
\hline Ireland & 131.4 & (1) & -25.3 & (1) & 72.9 & (9) & Yes \\
\hline Italy & 53.4 & $(12)$ & -7.9 & (6) & 41.2 & (14) & Yes \\
\hline Japan & -25.6 & (19) & -8.3 & (5) & -31.8 & (19) & No \\
\hline Netherlands & 61.0 & $(10)$ & -6.9 & (8) & 49.8 & (12) & Yes \\
\hline New Zealand & 64.2 & (9) & -1.7 & $(10)$ & 61.4 & (11) & Yes \\
\hline Norway & 53.0 & (14) & 24.3 & (18) & 90.2 & (6) & No \\
\hline South Korea & 4.4 & $(17)$ & 6.5 & (13) & 11.1 & (17) & No \\
\hline Spain & 108.6 & (3) & -20.8 & (3) & 65.3 & (10) & Yes \\
\hline Sweden & 83.4 & (5) & 16.0 & (16) & 112.9 & (1) & No \\
\hline Switzerland & 10.7 & (16) & 14.2 & (15) & 26.4 & (15) & No \\
\hline United Kingdom & 112.2 & $(2)$ & -7.3 & (7) & 96.6 & (5) & Yes \\
\hline
\end{tabular}

NOTE: Data for Canada and Denmark are available until only 2011:Q2; data for Ireland are available only until 2010:Q4. Thus, the "Bust" and "Overall" figures provide percent change values with these quarters as the end quarter. The numbers in parentheses indicate the international ranking within this group of 19 countries.

The second category consists of the countries that had a run-up in housing prices but experienced little or no bust in housing prices. Nine countries fall into this category. During the boom period, seven of these countries-Australia (78 percent), Belgium (55 percent), Canada (53 percent), Finland (68 percent), France (102 percent), Norway (53 percent), and Sweden (83 percent)—experienced larger run-ups in housing prices than the U.S. increase of 50 percent. Meanwhile, two of the nine countries - South Korea (4 percent) and Switzerland (11 percent) experienced smaller run-ups. Given the lack of a significant bust, eight of the nine countries experienced substantially larger increases in housing prices than the United States over the entire period. For example, the increases over the period for these eight countries ranged from 26 percent in Switzerland to 113 percent in Sweden. Only South Korea, with an increase of 11 percent, experienced an increase less than the U.S. increase of 16 percent.

We now focus on the seven countries with a boom and bust somewhat comparable to the U.S. boom and bust. While these countries experienced rising housing prices during the boom and falling prices during the bust, the magnitudes of the changes were often much different from those for the United States. For example, during the boom period, three countries-Ireland 


\section{Cohen, Coughlin, Lopez}

(131 percent), the United Kingdom (112 percent), and Spain (109 percent)—had inflationadjusted housing price increases that were more than double the U.S. rate of 50 percent. The remaining four countries-Denmark ( 80 percent), Italy (53 percent), the Netherlands (61 percent), and New Zealand (64 percent) - also had larger increases than the United States. During the bust, the (absolute) percentage declines in these seven countries were either roughly equal to or somewhat less than the U.S. decline. Overall, these seven countries-Denmark (45 percent), Ireland (73 percent), Italy (41 percent), the Netherlands (50 percent), New Zealand (61 percent), Spain (65 percent), and the United Kingdom (97 percent) - have had much larger increases than the U.S. increase of 16 percent.

\section{CONCLUSION}

The housing market in the United States continues to draw much attention. This paper attempts to summarize key changes in housing prices during recent years from both a national and a metropolitan-area perspective. In addition, our examination of 18 other advanced foreign economies reveals that the boom and bust of housing prices was not simply a U.S. event.

Using 1998:Q1 as the beginning of the boom and 2006:Q2 as the turning point separating the boom from the bust, several observations about housing prices can be made. From a national perspective, the $\mathrm{S} \& \mathrm{P} /$ Case-Shiller index more than doubled in nominal terms during the boom and has fallen by roughly a third subsequently. Overall, this index shows an increase of slightly less than 50 percent. Meanwhile, the FHFA Purchase-Only index shows a relatively smaller run-up during the boom ( 83 percent) and a relatively smaller decline during the bust (18 percent). However, the overall change in this index is slightly less than 50 percent, which is virtually the same as the change in the S\&P/Case-Shiller index. In inflation-adjusted terms, the overall change in the S\&P/Case-Shiller index is 14 percent and in the FHFA index is 16 percent.

An important development during the bust was the increasing frequency of distressed sales, which often exceeded 30 percent of total sales, which is far greater than during the boom. Given the downward price pressure associated with distressed sales, it is no surprise that the CoreLogic national housing price index including distressed sales has fallen more rapidly ( -31 percent) than one that excludes distressed sales ( -25 percent) during the bust period.

Major differences are seen across metropolitan areas with regard to housing price changes. While national developments played a key role in housing prices at the metropolitan level, various other factors undoubtedly also affected these prices. During the boom, housing prices tended to rise much faster in metropolitan areas on both coasts than in the interior. In the three metropolitan areas with the largest percentage increases-Los Angeles, San Diego, and Miami-nominal housing prices tripled.

During the bust, housing price declines across metropolitan areas also varied greatly. Three areas-Las Vegas, Phoenix, and Miami-experienced nominal declines of 50 percent or more. Meanwhile, housing prices in Denver and Charlotte declined 9 and 11 percent, respectively. Metropolitan areas with the larger booms tended to have the larger busts.

After adjusting for inflation, 7 of 19 metropolitan areas experienced real declines in housing prices from the start of the boom (1998:Q1) to the present (2012:Q1). Overall, housing prices 
declined the most in Detroit: 36 percent in inflation-adjusted terms. Meanwhile, on the other end of the spectrum, housing prices increased the most in Washington, D.C.: 55 percent in inflation-adjusted terms.

A number of regularities emerged when housing prices in metropolitan areas were separated by price. During the boom, houses in the low tier had the largest percentage increase, while houses in the high tier tended to have the smallest percentage increase. During the bust, houses in the low tier experienced the largest (absolute) percentage decrease, while houses in the high tier generally experienced the smallest (absolute) percentage decrease. Combining the two periods, the most favorable percentage price changes were generally found in the high tier.

Because the price of a house can be separated into the price of its physical structure and the price of the land on which it is located, we explored the limited evidence concerning the changes in the prices of these two components. It appears that changes in land prices, especially for cities on the coasts, have driven housing prices to a greater extent than changes in the prices of structures. However, Kuminoff and Pope (2011) suggest that the magnitude of this factor might be less than suggested by estimates of Davis and co-authors $(2007,2008)$.

Finally, during the present boom and bust it is clear that the United States was not alone. Of the 18 foreign countries reviewed, 7 experienced booms and busts roughly similar to the U.S. experience. However, these countries tended to have larger booms and smaller absolute busts. As a result, for the entire period these countries experienced larger inflation-adjusted increases in housing prices than the United States. A complete explanation of the U.S. experience might provide some insights that apply to these other countries. Moreover, the experiences of these 18 countries might provide instructive information for policymakers and others.

\section{NOTES}

1 Davis and Heathcote (2007) and Davis and Palumbo (2008) (see www.lincolninst.edu/subcenters/land-values/) estimate a decline in home values of more than $\$ 8$ trillion using the Standard and Poor's (S\&P)/Case-Shiller housing price index and $\$ 4$ trillion to $\$ 5$ trillion using the Federal Housing Finance Agency housing price index. A Federal Reserve Board white paper (Board of Governors of the Federal Reserve Board, 2012) reported that home equity since early 2006 had declined more than $\$ 7$ trillion.

$\underline{2}$ Boldrin et al. (2012) analyze the importance of housing in the Great Recession. See Anderson (2010) and Rueben and Lei (2010) for a discussion of the impact of housing prices on the public sector.

3 For example, Foote, Gerardi, and Willen (2012) conclude that borrowers and investors acted on overly optimistic beliefs about house prices rather than being deceived by financial industry insiders during the boom. Pinto (2011) explores how government housing policies contributed to the buildup and collapse of the housing and mortgage markets. Levitin and Wachter (2011) stress the role of an excess of mispriced mortgage financing. Taylor (2007) argues that the Federal Open Market Committee played a major role in the bubble by keeping the federal funds rate too low for too long. Glaeser, Gyourko, and Saiz (2008) develop a boom-bust model in which locations with a more elastic housing supply have relatively smaller price increases and fewer and shorter bubbles. For a discussion of the continuing weakness in the housing market, see the Federal Reserve Board white paper (2012). Weak labor market conditions and various housing market factors, such as a large number of houses for sale, a decline in the supply of mortgage credit, and a costly foreclosure process, are noted.

4 We also examine estimates by Kuminoff and Pope (2011).

$\underline{5}$ The S\&P/Case-Shiller national home price index is a quarterly index of single-family home prices. Based on a repeatsales methodology, the quality of houses used in the index is constant. The actual sales prices of homes are recorded, and when a specific house is resold, this new sales price is matched to its earlier sales price. The difference in this sale pair is aggregated with other sale pairs into an index. The FHFA house price index, produced by the Federal Housing Finance Agency, is also a repeat-sales index; it uses information on mortgage transactions for single-family proper- 


\section{Cohen, Coughlin, Lopez}

ties with mortgages purchased or securitized by the Federal National Mortgage Association (Fannie Mae) or Federal Home Loan Mortgage Corporation (Freddie Mac). See Rappaport (2007) for additional information on national indexes.

6 Various prices indexes could have been used for the inflation adjustment. Our use of the core inflation PCE index simply follows Davis and Heathcote (2007). In the section on international housing prices, we follow Mack and Martínez-García (2011) and use the respective country's headline inflation PCE index.

1 Rappaport (2007) discusses how the value weighting used in the S\&P/Case-Shiller index rather than weighting by the number of housing units as in the FHFA index might explain the relatively larger boom and bust in the former index. This weighting difference leads Rappaport (2007) to conclude that the FHFA index is better than the S\&P/CaseShiller index for estimating price changes for single-family houses, while the latter index provides a better estimate of the investment returns from owning a representative sample of U.S. homes.

8 See endnote 1 .

9 The Federal Reserve Board white paper (2012) reported that 12 million mortgages were underwater as of 2011:Q3, with aggregate negative equity of $\$ 700$ billion. For about 8.6 million of these mortgages, with $\$ 425$ billion in negative equity, borrowers were current on their payments.

10 Recent studies of the impact of foreclosures on housing prices include those by Leonard and Murdoch (2009); Immergluck and Smith (2006); Frame (2010); Lin, Rosenblatt, and Yao (2009); Rogers and Winter (2009); Sumell (2009); Schuetz, Been, and Ellen (2008); Harding, Rosenblatt, and Yao (2009); and Clauretie and Daneshvary (2009). One common finding is that foreclosed houses sell for less than otherwise comparable houses. For example, Campbell, Giglio, and Pathak (2011) found that over a 20-year period foreclosed houses in Massachusetts sold for 27 percent less than other comparable houses. A second common finding is that foreclosures lower the value of nearby houses. For houses that are 0.05 miles from a foreclosed house, Campbell, Giglio, and Pathak (2011) found a price decline of 1 percent. Meanwhile, for roughly the same distance, Hartley (2010) found a decline of 2 percent in highdensity Census tracts and a statistically insignificant effect in low-density Census tracts.

11 Determining the value of land used for residential housing is challenging. Indirect methods are typically used; however, some research has measured the value of vacant land, while other research has used plots with structures slated to be demolished (i.e., teardowns) and then replaced by new housing to measure land values. See Haughwout, Orr, and Bedoll (2008) and Dye and McMillen (2007).

12 See Davis and Heathcote (2006) for details on the data and methodology underlying their estimates. For up-to-date estimates, see the "Land and Property Values in the US" section of the Lincoln Institute of Land Policy website (www.lincolninst.edu/resources).

13 We exclude Dallas because of a lack of data before 2000. Also, the term "metropolitan area" does not necessarily mean metropolitan statistical area (MSA). For example, New York and Chicago are not identical to their MSAs. (See www.standardandpoors.com/indices/main/en/us. Click on the Economic tab and see S\&P Indices-S\&P/Case-Shiller Home Price Indices; choose Index Methodology, November 2009, from the menu on the left side of the page.)

14 Such variation across metropolitan housing markets is not surprising. Glaeser, Gottlieb, and Tobio (2012) found that higher initial prices, warmer winters, lower population density, and less-educated citizens explained more than 70 percent of the variation in price growth across 300 metropolitan areas between 1996 and 2006. A major research challenge is pinning down the effects of national and local factors in explaining housing price dynamics. In addition to local factors, Saks (2008) finds that national shocks have different effects on housing prices across metropolitan areas.

15 Given the differential in housing prices in these two areas, the two houses are not assumed to be identical.

16 A comparable house would have sold for a higher price in Los Angeles than in Cleveland at the beginning of the boom, so the difference in prices for a comparable house at the end of the boom would have exceeded $\$ 200,000$.

17 During both the boom period and the entire period, the metropolitan area with the largest increase is ranked 1 , while the area with the smallest increase is ranked 19. During the bust period, the metropolitan area with the largest (absolute) decrease is ranked 1, while the area with the smallest (absolute) decrease is ranked 19.

18 For additional details on these indexes, see Davis and Heathcote (2006).

19 This result is likely due to statistical as well as financial reasons. See the Lincoln Institute of Land Policy website (endnote 12) for a statistical reason, termed a "value effect." Armesto and Garriga (2009) suggest that buyers in the low tier were affected to a larger degree by some financial factors that contributed to the boom and bust. Interest-only loans and increasing opportunities to purchase with no or a very small down payment were likely more important for those purchasing lower-priced houses than for those purchasing higher-priced houses. 


\section{Cohen, Coughlin, Lopez}

20 The Federal Reserve Board white paper (2012) highlights a large decline in demand for a group that generally purchased low-tier housing. The share of 29- to 34-year-olds acquiring a mortgage for the first time between mid-1999 and mid-2001 was 17 percent, but this share was 9 percent between mid-2009 and mid-2011.

21 The appendix lists the 46 metropolitan areas and their grouping into regions.

$\underline{22}$ See Table 3 in Kuminoff and Pope (2011) for the numerical estimates. Within metropolitan areas during the boom, the premiums tended to be most pronounced for structures in high-amenity neighborhoods.

$\underline{23}$ Kuminoff and Pope (2011) find that their results outside the bubble period are similar to those of Davis and Palumbo (2008).

$\underline{24}$ The preceding discussion about the relative importance of land and structure price changes for housing price changes is connected to the elasticity of housing supply. Accurate measures of this elasticity are crucial for identifying the share of a price change that should be attributed to fundamentals. In addition to Glaeser, Gyourko, and Saiz (2008), Goodman and Thibodeau (2008) have explored the effects of different elasticities across metropolitan areas. They conclude that much of the large increases in housing prices on the East Coast and in California, where they also tend to find speculative activity, can be attributed to inelastic supply.

$\underline{25}$ See the Dallas Fed's International House Price Database (www.dallasfed.org/institute/houseprice/index.cfm) and Mack and Martínez-García (2011). The Dallas Fed's database contains housing price information for Australia, Belgium, Canada, Denmark, Finland, France, Germany, Ireland, Italy, Japan, the Netherlands, New Zealand, Norway, South Korea, Spain, Sweden, Switzerland, the United Kingdom, and the United States.

26 Nominal housing prices, which are seasonally adjusted and then rebased so that $2005=100$, are deflated by the country's PCE deflator.

\section{REFERENCES}

Anderson, John E. "Shocks to the Property Tax Base and Implications for Local Public Finance." Unpublished manuscript, 2010, University of Nebraska-Lincoln; www.taxpolicycenter.org/events/upload/Anderson-paper.pdf.

Armesto, Michelle T. and Garriga, Carlos. "Examining the Housing Crisis by Home Price Tier." Federal Reserve Bank of St. Louis Monetary Trends, August 2009; http://research.stlouisfed.org/publications/mt/20090801/cover.pdf.

Board of Governors of the Federal Reserve System. "The U.S. Housing Market: Current Conditions and Policy Considerations." White paper, January 4, 2012; http://federalreserve.gov/publications/other-reports/files/housing-white-paper-20120104.pdf.

Boldrin, Michele; Garriga, Carlos; Peralta-Alva, Adrian and Sanchez, Juan. "Reconstructing the Great Recession." Unpublished manuscript, Federal Reserve Bank of St. Louis, May 2012.

Campbell, John Y.; Giglio, Stefano and Pathak, Parag. "Forced Sales and House Prices." American Economic Review, August 2011, 101(5), pp. 2108-31.

Clauretie, Terrence M. and Daneshvary, Nasser. "Estimating the Home Foreclosure Discount Corrected for Spatial Price Interdependence and Endogeneity of Marketing Time." Real Estate Economics, 2009, 37(1), pp. 43-67.

Davis, Morris A. and Heathcote, Jonathan. "Appendix to 'The Price and Quantity of Residential Land in the United States."' University of Wisconsin-Madison, November 2006; www.marginalq.com/morris/landdata files/2006-11-Davis-Heathcote-Land.appendix.pdf.

Davis, Morris A. and Heathcote, Jonathan. "The Price and Quantity of Residential Land in the United States." Journal of Monetary Economics, November 2007, 54(8), pp. 2595-620.

Davis, Morris A. and Palumbo, Michael G. "The Price of Residential Land in Large US Cities." Journal of Urban Economics, January 2008, 63(1), pp. 352-84.

Dye, Richard F. and McMillen, Daniel P. "Teardowns and Land Values in the Chicago Metropolitan Area." Journal of Urban Economics, January 2007, 61(1), pp. 45-63.

Foote, Christopher L.; Gerardi, Kristopher S. and Willen, Paul S. "Why Did So Many People Make So Many Ex Post Bad Decisions? The Causes of the Foreclosure Crisis." Public Policy Discussion Paper Series No. 12-2, Federal Reserve Bank of Boston, May 2012; www.bos.frb.org/economic/ppdp/2012/ppdp1202.pdf. 


\section{Cohen, Coughlin, Lopez}

Frame, W. Scott. "Estimating the Effect of Mortgage Foreclosures on Nearby Property Values: A Critical Review of the Literature." Federal Reserve Bank of Atlanta Economic Review, 2010, 95(3), pp. 1-9; www.frbatlanta.org/documents/pubs/economicreview/er10no3 frame.pdf.

Glaeser, Edward L.; Gottlieb, Joshua D. and Tobio, Kristina. "Housing Booms and City Centers." American Economic Review: Papers and Proceedings, May 2012, 102(3), pp. 127-33.

Glaeser, Edward L.; Gyourko, Joseph and Saiz, Albert. "Housing Supply and Housing Bubbles." Journal of Urban Economics, September 2008, 64(2), pp. 198-217.

Goodman, Allen C. and Thibodeau, Thomas G. "Where Are the Speculative Bubbles in U.S. Housing Markets?" Journal of Housing Economics, June 2008, 17(2), pp. 117-37.

Harding, John P.; Rosenblatt, Eric and Yao, Vincent W. "The Contagion Effect of Foreclosed Properties." Journal of Urban Economics, November 2009, 66(3), pp. 164-78.

Hartley, Daniel. "The Effect of Foreclosures on Nearby Housing Prices: Supply or Disamenity?" Working Paper No. 10-11, Federal Reserve Bank of Cleveland, September 2010, revised December 2011; www.clevelandfed.org/research/workpaper/2010/wp1011r.pdf.

Haughwout, Andrew F.; Orr, James and Bedoll, David. "The Price of Land in the New York Metropolitan Area." Federal Reserve Bank of New York Current Issues in Economics and Finance, 2008, 14(3); www.newyorkfed.org/research/current issues/ci14-3.pdf.

Immergluck, Dan and Smith, Geoff. "The External Costs of Foreclosure: The Impact of Single-Family Mortgage Foreclosures on Property Values." Housing Policy Debate, 2006, 17(1), pp. 57-79; www.nw.org/network/neighborworksProgs/foreclosuresolutions/pdf docs/hpd 4closehsgprice.pdf.

Kuminoff, Nicolai V. and Pope, Jaren C. "The Value of Residential Land and Structures during the Great Housing Boom and Bust." Working Paper No. WP11NK1, Lincoln Institute of Land Policy, July 2011; www.lincolninst.edu/pubs/dl/1965 1286 KuminoffPope Final.pdf.

Leonard, Tammy C. and Murdoch, James C. "The Neighborhood Effects of Foreclosures." Journal of Geographical Systems, December 2009, 11(4), pp. 317-32.

Levitin, Adam J. and Wachter, Susan M. “Explaining the Housing Bubble." Georgetown Law Journal, April 2012, 100(4), pp. 1177-258; http://georgetownlawjournal.org/files/2012/04/LevitinWachter.pdf.

Lin, Zhenguo; Rosenblatt, Eric and Yao, Vincent W. "Spillover Effects of Foreclosures on Neighborhood Property Values." Journal of Real Estate Finance and Economics, May 2009, 38(4), pp. 387-407.

Mack, Adrienne and Martínez-García, Enrique. "A Cross-Country Quarterly Database of Real House Prices: A Methodological Note." Federal Reserve Bank of Dallas Globalization and Monetary Policy Institute Working Paper No. 99, December 2011, revised February 2012; www.dallasfed.org/assets/documents/institute/wpapers/2011/0099.pdf.

Pinto, Edward J. "Government Housing Policies in the Lead-up to the Financial Crisis: A Forensic Study." American Enterprise Institute Papers and Studies, February 5, 2011; www.aei.org/papers/economics/financial-services/housing-finance/government-housing-policies-in-the-lead-upto-the-financial-crisis-a-forensic-study/.

Rappaport, Jordan. "A Guide to Aggregate House Price Measures." Federal Reserve Bank of Kansas City Economic Review, Second Quarter 2007, 92(2), pp. 41-71; www.kc.frb.org/PUBLICAT/ECONREV/PDF/2q07rapp.pdf.

Rogers, William H. and Winter, William. "The Impact of Foreclosures on Neighboring Housing Sales." Journal of Real Estate Research, 2009, 31(4), pp. 455-79; http://aux.zicklin.baruch.cuny.edu/jrer/papers/pdf/past/vol31n04/04.455 480.pdf.

Rueben, Kim and Lei, Serena. "What the Housing Crisis Means for State and Local Governments." Lincoln Institute of Land Policy Land Lines, October 2010, pp. 8-13; www.taxpolicycenter.org/uploadedpdf/1001459-Housing-Crisis.pdf.

Saks, Raven E. "Reassessing the Role of National and Local Shocks in Metropolitan Area Housing Markets." BrookingsWharton Papers on Urban Affairs, 2008, No. 9, pp. 95-126; http://muse.jhu.edu/journals/brookings-wharton_papers on urban affairs/v2008/2008.saks.pdf.

Schuetz, Jenny; Been, Vicki and Ellen, Ingrid Gould. "Neighborhood Effects of Concentrated Mortgage Foreclosures." Journal of Housing Economics, December 2008, 17(4), pp. 306-19. 
Sumell, Albert J. "The Determinants of Foreclosed Property Values: Evidence from Inner-City Cleveland." Journal of Housing Research, 2009, 18(1), pp. 45-61.

Taylor, John B. "Housing and Monetary Policy," in Housing, Housing Finance, and Monetary Policy. Federal Reserve Bank of Kansas City Symposium, Jackson Hole, Wyoming, August 30-September 1, 2007, pp. 463-76; www.kansascityfed.org/PUBLICAT/SYMPOS/2007/PDF/Taylor 0415.pdf.

APPENDIX

Metropolitan Areas and Their Grouping into Regions (Davis and co-authors, 2007, 2008)

\begin{tabular}{|c|c|c|c|}
\hline Region & Cities & Region & Cities \\
\hline \multirow[t]{13}{*}{ Midwest } & Buffalo & East Coast & Baltimore \\
\hline & Chicago & & Boston \\
\hline & Cincinnati & & Hartford \\
\hline & Cleveland & & Miami \\
\hline & Columbus & & New York City \\
\hline & Detroit & & Norfolk \\
\hline & Indianapolis & & Philadelphia \\
\hline & Kansas City & & Providence \\
\hline & Milwaukee & & Washington, D.C. \\
\hline & Minneapolis/St. Paul & West Coast & Los Angeles \\
\hline & Pittsburgh & & Oakland \\
\hline & Rochester & & Portland \\
\hline & St. Louis & & Sacramento \\
\hline \multirow[t]{5}{*}{ Southeast } & Atlanta & & San Bernardino \\
\hline & Birmingham & & San Diego \\
\hline & Charlotte & & San Francisco \\
\hline & Memphis & & San Jose \\
\hline & Tampa & & Santa Ana \\
\hline \multirow[t]{9}{*}{ Southwest } & Dallas & & Seattle \\
\hline & Denver & & \\
\hline & Fort Worth & & \\
\hline & Houston & & \\
\hline & New Orleans & & \\
\hline & Oklahoma City & & \\
\hline & Phoenix & & \\
\hline & Salt Lake City & & \\
\hline & San Antonio & & \\
\hline
\end{tabular}




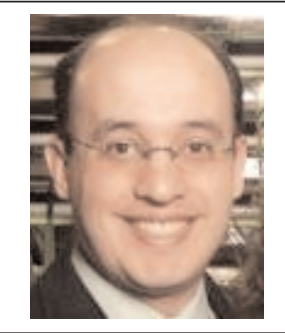

\section{Jeffrey P. Cohen}

Associate professor of economics, University of Hartford

http://www.hartford.edu/barney/faculty/cohen.aspx

\section{Research Focus}

Professor Cohen is an applied microeconomist with specific interests in applying spatial econometrics techniques to problems in the areas of urban and regional economics; transportation, land use, and housing; and environmental and health economics.

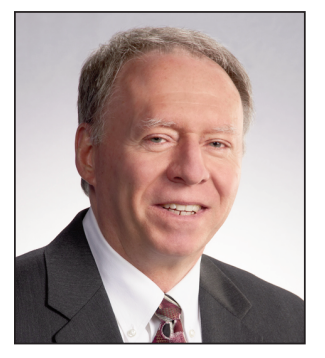

\section{Cletus C. Coughlin}

Senior vice president and policy adviser to the president, Federal Reserve Bank of St. Louis

http://research.stlouisfed.org/econ/coughlin/

\section{Research Focus}

Cletus Couglin's research focuses on regional economics and international trade.

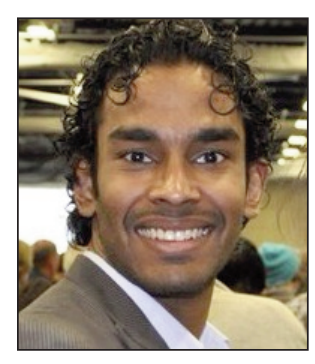

\section{David A. Lopez}

Senior research associate, Federal Reserve Bank of St. Louis

\section{Research Focus}

David Lopez currently assists Cletus Coughlin and David Wheelock with their research in economic history, banking, and international trade. His research interests also include economic development and public policy. 